\title{
An Empirical Study of High Performance HRM Practices in Chinese SMEs
}

\begin{abstract}
This paper explores the performance effects of Human Resource Management (HRM) practices in seventy-four Chinese small and medium sized enterprises (SMEs). Four high performance HRM practices are identified: performance-based pay, participatory decision making, free market selection, and performance evaluation. Regression analysis results support the conventional idea that the adoption of HRM practices generates better HRM outcomes and, in turn, better HRM outcomes contribute positively to firm performance. However, not all HRM practices, and their effects, led to improved SME performance. Among the Chinese SMEs investigated, a high level of employee commitment was identified as being the key HRM outcome for enhancing performance.
\end{abstract}

\section{Keywords}

China, human resource management practices, SME performance, employee commitment

\section{Introduction}

There has been a long range of theoretical discussions ( eg. Beer et al. 1984; Devanna et al. 1984; Guest 1997; Wood 1999; Paauwe 2004) and empirical testings (eg. Arthur 1994; MacDuffie 1995; Huselid 1995; Youndt et al. 1996; Huselid et al. 1997; Ngo et al. 1998; Kaman et al. 2001; Guthrie 2001; Guest et al. 2003; Bartel 2004; Wright et al. 2005; Stavrou and Brewster 2005) of the relationship between HRM and firm performance. Yet these theoretical and empirical studies have generally focused on HRM practices within Western organisations. Relatively little is known about the impact of HRM on firm performance in Asian countries, and this is especially so in relation to China. Further, the majority of existing studies of HRM have focused on HRM practices in large and medium-sized firms. The few reported studies, which have examined HRM practices and their effects in China, have also been based on large stateowned enterprise and/or multinational companies (eg. Lu and Bjorkman 1997; Goodall and Warner 1997; 1999; Li 2003; Lewis 2003; Ahlstrom et al. 2005). There has been a pronounced lack of focus on the impact of HRM on firm performance among Chinese small and medium sized enterprises (SMEs).

This paper contributes to knowledge of the impact of HRM by testing the performance effects of adopting HRM practices in Chinese SMEs. Based on the data from 74 Chinese SMEs, 
quantitative analysis is used to test the relationship between the adoption of HRM practices and SME performance. The results indicate that several high performance HRM practices do influence performance among the SMEs investigated.

The remainder of the paper is structured as followed. A literature review of past research on HRM and performance is presented. A conceptual framework of the HRM-performance link, in the context of Chinese SMEs (de Kok and Uhlaner 2001; Chow 2004b), is developed and hypotheses are proposed. The discussion then moves to the research method selected for testing these hypotheses, followed by discussion of the data analysis. The paper concludes by exploring implications of the key findings and suggesting directions for future research.

\section{Performance Effects of HRM}

\section{Theoretical Models of HRM and Performance}

There are basically three schools of thoughts in regard to building a HRM-performance model. The first adopts a universalist approach. Scholars in this camp argue that better organisational performance can be achieved through a greater use of 'high performance' HR practices such as incentive pay, training and skill development, employee participation and job security (Huselid 1994; 1995; Pfeffer 1994, 1998). In another word, the more comprehensive HR practices, the better firm performance would be. Earlier discussions on building HRM theory tend to focus on this approach, whereby many theoretical models developed then were mostly descriptive or prescriptive, without addressing specifically what constitutes of a comprehensive set of HR practices. The universalists contend that if managers make right HR choices, adopting and implementing prescribed one or more HR practice (s), the overall employee commitment, quality of employees and flexibility will be the result. This in turn would lead to achieving organizational goals such as productivity, profits, efficiency and effectiveness (Beer et al. 1984; Guest 1987; 1997; Schuler and Huber 1993; 1997).

The second view is that of institutionalism, which is closely linked to the system theory, contingency theory and resource-based theory. Scholars in this group advocate that for HRM to be effective, 'high performance' work practices must be consistent with the internal HRM system (Devannan et al. 1984) and external environment (Begin 1992). The internal HR system needs to be able to generate a pool of skills and experience in the workforce that is unique, rare and idiosyncratic (Barney 1991), which other organizations can not easily imitate or substitute. This internal pool of human capital is able to respond to market demands and changes effectively 
so as to enhance organizational performance (Adler 1988; Chow 2004b). From the external institutional point of views, measuring the effects of HRM on performance must also be contextbased as practices fit for one context may not be necessarily effective for another (Pieper 1990; Begin 1992). Managers need to take into consideration a series of factors such as external labour market conditions, institutional and legal framework within a particular nation where companies are operating, other than HRM to measure the overall organizational performance (Jackson and Schuler 1995; Dowling et al. 1999; Paauwe 2004).

The last one is the strategic approach, which has become the most recent subject of discussion in regard to HRM and performance. The strategic HRM theorists have attempted to integrate patterns of SHRM-related practices to firm business strategy and test their effects on firm performance (Devanna et al. 1981; Wright and McMahan 1992; Becker, Husleid and Ulrich 1999; Gratton et al. 1999; Boxall and Purcell 2003), and see what HR practices truly offer deliverables in terms of administrative efficiency, employee contribution, business strategy execution and organizational capacity for change (Ulrich 1997; 1998; Becker, Huselid and Ultrich 2001). Testing the effectiveness of SHRM practices tend to focus on a configurational approach, whereby two or more sets of HRM practices are combined in different forms to test their greater effects on implementing firm business strategy, therefore, eventually impacting on performance (Snell, Youndt and Wright 1996). As Marchington and Grugulis (2000) explain more fully in this strategic view of linking HRM to performance, 'HRM practices cannot be implemented effectively in isolation and that it is the combination of practices into a coherent package that matters' (cited from Stavrou and Brewster 2005, p. 190). The problem with this approach is that there is little shared understanding of what SHRM activities are, and how they could facilitate effective implementation of firm's business strategy.

Along with the continuing debates on universalism, institutionalism and strategic particularism, numerous models of HRM have been developed in the literature. For the purposes of this study, five well known models (see Table 1) that focus on the linkage between HRM and organisational performance were selected for comparison and use. These models have their focus on the HRM practices (independent variables), HRM outcomes and performance indicators (dependent variables), and other internal and external factors (control variables) that we found to be most relevant to the study of HRM and its performance effects in Chinese SMEs.

A common feature of the five models presented in Table 1 is that there is an explicit link between HRM and performance. These models address key ideas about HRM and effectively 
offer a map of the field. They classify HRM inputs and outcomes, and indicate the relatedness between practices, outcomes and performance. However, despite the commonalities, these models do not provide researchers with a consistent and unified list of HRM practices, outcomes and performance indicators for empirical testing (see later discussion). For example, there are substantial differences between the earlier and later models in terms of the HRM practice variables, with greater elaboration in the later models. Even amongst the later models, there is substantial variation amongst the HR outcome variables and measures of firm performance. Further, Devanna et al. (1984), Schuler and Huber (1993) and Schuler (1997) do not specify HRM outcome variables, which are specified in the other models.

Given the nature of the current study, we will need to explore the potential link between HRM practices and their effects on small and medium-sized enterprises in China. With a general lack of studies in the field of HRM and SMEs in China, there is a need to explore a universal set of HRM practices to find out what works better for Chinese SMEs. The context-based analysis of HRM is also important, because without context, HRM may lose its interpretative meaning when practiced in different countries (Pieper 1990; Brewster 1993; Chow 2004b; Paauwee 2004). Likewise, the impact of institutional context on HRM within large and small firms has been widely studied in the past (eg. de Kok and Uhlaner 2001; Kotey and Sheridan 2004). So our focus will be mainly on examining the impact of HRM on Chinese SMEs, with consideration of institutional impact on SMEs. There has also been an increasing awareness of the strategic position of SMEs and its vital importance in adopting strategic HRM activities (Brand and Bax 2002). However, because of ambiguity of what consisted of SHRM activities for SMEs and a problematic transition to a strategic role of HRM in Chinese enterprises (Zhu et al. 2005), the current study will focus on examining HRM outcomes that are mostly likely to be sought after by Chinese SMEs to achieve their high level business performance.

\section{<Table 1 about here >}

\section{Empirical Studies of HRM and Performance}

Throughout the past decade, there have been a significant number of empirical studies conducted to examine the effects of HRM practices on performance. The most noticeable and widely cited ones are Arthur (1994), MacDuffie (1995), Huselid (1995), Youndt et al. (1996) and Huselid et al. (1997) who have examined the impact of technical and strategic HRM on firm performance in the context of American firms. Since then, similar studies were also conducted 
in other countries, for example, Lähteenmäki et al (1998) examined HRM practices and company performance in 428 Finnish companies, Guthrie (2001) looked at the relationship between highinvolvement work practices and firm performance in 128 New Zealand companies. Guest et al. (2003) used both cross-sectional and longitudinal data of 366 UK companies and found that a greater use of HRM is positively associated with lower staff turnover and better company's financial performance. Most recently, Wright et al. (2005) explored 45 self-contained business units of a large food-service multinational company operating in the US and Canada, using correlation of measures of HRM practices with past, concurrent and future operational performance measures. They made a bold claim that there is a positive casual relationship between HR practices and firm performance, supporting a universalist theory. A grandiose study conducted by Stavrou and Brewster (2005), using the data of 3702 organizations from most of the EU member countries, seems lending the support of such claim, except they came to the conclusion from a strategic particularist point of view. Stavrou and Brewster (2005, p. 197) stated that 'the link of Strategic HR Bundles to business performance in the EU is not a myth', but a reality.

It is noted that various statistical methods have been adopted in these empirical studies. Regression analysis was often used in measuring the effect of HR bundles on objective and perceptual performance indicators such as sales growth, shareholder return and profitability. Standard and binary regressions were both used depending on the methods selected to measure the dependent variables. Factor analysis and cluster analyses were also used in the analyses to assess the effects of multiple HRM practices on organisational performance.

We selected here a number of these empirical studies that have shown the impact of a 'bundle' of HRM practices on organisational performance as they are related to the current study. The value of the 'bundle' approach is that, within a holistic HRM system, the factors that most contribute to performance can be identified, and the interaction between different HRM practices can be observed (MacDuffie 1995; Snell, Youndt and Wright 1996). While several studies have been undertaken in this area, what constitutes a 'bundle' has not been unanimously agreed upon in the literature (Becker and Gerhart 1996; Wood 1999; Stavrou and Brewster 2005). This is evident in the studies summarized in Table 2 which have all examined how bundles of HRM practices influence HRM outcomes and firm performance.

In examining Table 2, it is also apparent that most of these empirical studies have focused on large organisations. For example, Huselid (1995) and Guthrie (2001) selected firms 
with a total number of employees over 100, and Ngo et al. (1998) ruled out organisations with total employees less than 50. As such, the generalisation of the study results to SMEs is likely to be subjective because there might be substantial differences in HRM practices between small and large firms (Watson et al. 1994; Kotey and Sheridan 2004).

\section{$<$ Table 2 about here $>$}

\section{HRM in SMEs}

Most discussion of HRM in SMEs has focused on comparisons of HRM practice in small and large firms (for example, McEvoy 1984; Watson et al. 1994; Deshpande and Golhar 1994; Golhar and Deshpande 1997; Hornsby and Kuratko 1990; 2003). Where the focus was more exclusively upon the investigation of HRM issues in small and medium sized enterprises, there was often a concentration upon identification of problems in the areas of selection, recruitment, compensation, empowerment, training and the role of trade unions (see for example, Rainnie 1989; Ram 1991; Caroll et al. 1999; Wyer and Mason 1999; de Kok and Uhlaner 2001; Szamosi, Duxbury and Higgins 2004). Few studies addressed the different impact of HRM on SMEs and large firms. Further, where there was a focus upon SMEs, such studies tended to examine the existence of HRM practices without examining the impact of the HRM practices on performance. Several studies have examined the impact of management training on SME performance (Marshall et al. 1995; Westhead and Storey 1996; Wong et al. 1997), but the results have indicated only a weak relationship between management training and SME performance.

While there has been very little research into the performance effects of HRM adoption on SMEs, a common thread in the arguments presented in prior studies on HRM in SMEs is that as SMEs grow, unsophisticated people management approaches become increasingly inadequate (Kaman et al. 2001; Kotey and Slade 2005). When this occurs, owners and managers of SMEs may come to realise the importance of formally adopting HRM systems and the associated benefits of nurturing people's creativity, and even the creation of competitive advantage and growth through people (Bacon et al. 1996; Kerr and McDougall 1999; Kaman et al. 2001; Kotey and Slade 2005).

Even though there appears to be recognition of the importance of HRM amongst SMEs, the empirical evidence on the extent of the impact of HRM practices on SME performance is inconclusive, especially in Chinese enterprises. It is, therefore, necessary that we address the 
development of HRM practices in Chinese SMEs to give institutional context to our later analysis and discussion of the effects of HRM practices on SME performance.

\section{HRM Practices in Chinese SMEs}

Since the commencement of economic reforms in 1978, China has increasingly engaged with the international economy. This is evidenced by the growth in direct and joint venture investment in China by multinational companies (MNCs) (China Statistics Yearbook 2004; World Bank 2005; Ahlstrom et al. 2005). An increase in foreign direct investment (FDI) has led to greater adoption of Western production techniques and management ideas in Chinese enterprises. However, in China, the adoption of HRM practices, especially in large state-owned enterprises (SOE) and joint ventures (JVE), appears to be uneven and fragmented (Warner 1993; Child 1994; Brown and Branine 1996; Benson and Zhu 1999; Lewis 2003; Chow 2004a; 2004b; Zhu et al. 2005). It has been argued that this phenomenon of partial adoption of HRM practices is largely due to strong government intervention, diversity of ownership and the nature of management styles existing in the Chinese transitional economy (Wright et al. 1998; Goodall and Warner 1999; Zhu and Warner 2002; Li 2003; Zhu et al. 2005).

Given the restrictions faced by larger firms in fully adopting HRM practices, it is possible that smaller firms may be in the vanguard of adopting HRM practices, as they often have greater freedom in their employment practices, and operate in a more flexible way than large companies. Goodall and Warner (1997) observed that small, new, high-tech enterprises in China that primarily employ younger workers were often the drivers of management change. They were, for example, better able to use HRM as a management tool in implementing changes and achieve improved performance in the process of restructuring, when compared to large SOEs (Chow 2004a).

However, there has been limited research into the effect of HRM on SME performance in China. Most studies on the development of HRM practices in Chinese enterprises tended to focus on understanding how Chinese practices compare with those in the West (see for example Tsang 1994; Ding, Fields and Akhtar 1997; Goodall and Warner 1997; Lu and Bjorkman 1997; Zhu and Warner 2002; Ahlstrom et al. 2005). Several studies have focused on some HRM practices and their impact on enterprise performance, but they have mostly dealt with a single HRM practice and its effect on firm performance. For example, Child (1995) focused on compensation policy in six large state-owned enterprises and measured its impact on firm performance. In another study, Zhu (1997) examined the impact of training and development 
programs on the effectiveness of the operation of 440 companies (the size of companies was not specified). Using Zhu's (1997) data, Zhu and Dowling (2000) explored the impact of hiring practices on employee job satisfaction and organisational effectiveness. Most recently, Ng and Siu (2004) adopted Zhu’s (1997) approach, and investigated 485 companies based in Shanghai. They identified a positive relationship between training expenditures and enterprise productivity.

A few empirical studies have been conducted that have examined the influence of a 'bundle' of HRM practices on firm performance, but these have focused on large and mediumsized firms. Two of these studies were qualitative in nature. For example, Benson and Zhu (1999) modified Storey's (1992) 27 points representing HRM and used this conceptualisation as the basis for interviewing managers in six large SOEs in Shanghai. Zhu and Warner (2002) adopted the approach set out by Gospel (1992) and examined three labour management categories in terms of job design, employment relations and industrial relations in their case study of eight medium to large sized enterprises in Hainan Special Economic Zone. More recently, a quantitative study has been undertaken by Li (2003) which measured the impact of strategic HRM using five HRM measures on the performance of 296 MNCs in China.

Thus, previous empirical studies focused primarily on large and medium sized as well as on multinational joint venture companies in China. The influence of HRM practices on SME performance in China, especially when multiple practices are used, is not well understood. Therefore, this study aims to examine a set of HRM practices adopted in Chinese SMEs, and to explore the key HRM practices that lead to better HRM outcomes, and in turn firm performance.

\section{$<$ Figure 1 about here $>$}

The conceptual model that is tested in this paper is presented in Figure 1. While the theoretical studies discussed above generally affirm the idea that HRM has a positive impact on firm performance, there has been less agreement about which HRM practice and outcome variables should be tested. Hence, the task of choosing independent variables for the conceptual model is not straightforward. The selection of variables for inclusion in the conceptual model is based on three criteria. First, they must have been used in previous studies in the literature. Second, they must be relevant to SMEs, and third they must reflect recent development of HRM practices in Chinese SMEs. Using these criteria, seven HRM practice variables have been included in the conceptual model. These are free market selection, performance based pay, the provision of social security benefits, training and development, performance evaluation, 
employee involvement in decision making and a role for trade unions. Using the first two criteria, four HRM outcome variables were selected: staff turnover, commitment, convergence and competency. Convergence in this context refers to the convergence of an employee's goals with that of the SME. Three measures of firm performance have been selected. These are: increased production and sales, market competitiveness and expected growth. These measures have all previously been used in the literature to indicate firm performance, and are relevant for SMEs. Several control variables have also been included, as shown in Figure 1.

This conceptual model will enable the testing of two main hypotheses, as follows:

Hypothesis 1: Chinese SMEs that follow the seven HRM practices listed will achieve better HRM outcomes than those that do not.

Hypothesis 2: Better HRM outcomes achieved by Chinese SMEs will lead to better enterprise performance.

\section{Research Methodology}

The methodology used for this study was influenced by the difficulties associated with sampling small to medium enterprises in China. A mail survey was initially conducted of 330 managers of SMEs identified by SME experts in the UNCTAD (United Nation's Conference for Trade and Development) Beijing office. However, despite two follow-ups, the response rate was less than $10 \%$. To ensure a more satisfactory response rate, it was necessary to conduct inperson interviews of SME managers in various cities in China. This approach has been used by other researchers in China to collect quantitative data (eg Child 1995, Lu and Bjorkman 1997; Warner 1997; Wright et al. 1998; Li 2003; Ahlstrom et al. 2005). While this involved the use of a non-probability sampling technique, the difficulty of using probability based sampling approaches to survey SME managers in China means that this sampling method would arguably have achieved greater representativeness of the population of interest than a probability based approach (Malhotra et al. 1996; Tabachnick and Fidell 2000). Three criteria were established for selecting firms to sample:

- Between 20-500 employees

- Annual sales of $100,000-5,000,000$ (about US\$10,000 to $\$ 500,000$ )

- Have been operating for at least three years 
The first two criteria ensure that the firms sampled are SMEs, while the remaining criterion is necessary so that it will be possible to test the effect of HRM practices on SME performance. No limitations were specified in terms of the form of firm ownership, or the type of industry that a firm operated in. Rather, firms from a variety of industries and with several different forms of ownership were included in the sample (Zhu 1997).

A total of 80 managers of SMEs were interviewed in 10 cities across China during September - October 1996 and October-November 1997 (see Table 3). However, because of excessive item non-responses in several of the interviews, six companies were excluded from the final analysis.

\section{$<$ Table 3 about here $>$}

Semi-structured interviews were used for this survey, with all interviews conducted in Mandarin by the first author of this paper. The questionnaire was designed to collect data that would enable testing of the conceptual model presented in Figure 1. Hence, information was collected about firms' HRM practices, their HRM outcomes and performance indicators. Data on covariates were needed, so questions were also asked about the firm's environment and the characteristics of the SME (eg industry, ownership and years of establishment).

Data on the variables in the conceptual framework were coded using the information collected from the interviews. The data obtained through the use of semi-structured interviews are mostly descriptive and categorising responses can be difficult. Therefore, to ensure greater comparability between respondents, binary variables $(0,1)$ and categorical variables $(0,1,2)$ were used. For example, when coding the HRM practice variable free market selection (FMS), firms that do not practice FMS at all were coded as zero; those who recruit between 1-99\% of their employees through the market were coded as 1, and those who fully practice FMS (ie recruit $100 \%$ of their employees through the market) were coded as 2 . All of the HRM outcome and firm performance variables were coded as binary variables because most of the responses to these questions tended to be dichotomous. This approach is consistent with previous research on HRM practices and their effect on firm performance (eg. Delaney and Huselid 1996; Lähteenmäki et al. 1998; Ngo et al. 1998; Guthrie 2001; Stavrou and Brewster 2005). 
In terms of analysis, techniques are needed that are capable of demonstrating the effect of changes in the use of HRM practices on HRM outcomes, and the effect of changing HRM outcomes on firm performance. Regression is often used to show the effect of changing independent variables on a dependent variable. However, the independent variables in this data set (eg the HRM practice variables), were found to be correlated which may cause problems with multicollinearity, which can lead to parameter estimates in regression equations being both biased and inefficient. For instance, coefficients may have the incorrect sign, or the summary statistics may indicate that a variable is insignificant when the converse is true. One alternative for dealing with this problem is to first reduce the data using factor analysis, then pursue regression analysis (Hair et al. 1998; Tabachnick and Fidell 2000). In a factor analysis a larger number of correlated variables are reduced into a smaller set of underlying constructs. Each construct is a linear combination of the existing variables. For example, several HR practice variables may be highly correlated as they all relate to performance evaluation. Factor analysis would mathematically combine these correlated variables into a single construct relating to performance evaluation. In addition, when conducting factor analysis it is possible to create uncorrelated constructs by specifying an orthogonal rotation, such as varimax. These constructs can then be included in a regression equation without causing multicollinearity. This was the procedure used in this study, to first analyse the data using principal components factor analysis with a varimax rotation, and then include the constructs derived from the factor analysis in regression equations. Principal components analysis was selected for this analysis as the technique uses the total information on each variable (rather than shared variance only), which is important if the constructs are to be used in subsequent analysis (Hair et al. 1998; Tabachnick and Fidell 2000). Factor analysis was conducted using the HRM practice variables for the testing of Hypothesis 1, and the HRM outcome variables for the testing of Hypothesis 2.

In terms of the regression analysis, binary logistic regression was used as the dependent variables (for both HRM outcomes and firm performance) are dichotomous (ie a firm achieves an outcome or it does not). In a binary logistic regression, the dependent variable is the log of the odds-ratio, which indicates the probability that an outcome will occur. Hence by using binary logit regression, for the first hypothesis we are able to model how the probability that a firm will achieve certain HRM outcomes changes as a function of their utilizing HRM practices and various control variables. The same approach is used for the testing of hypothesis two. 


\section{Results}

Before presenting the results of the two hypothesis tests, the use of HRM practices amongst the SMEs surveyed is summarized. This provides perspective on the usage of HRM practices amongst Chinese SMEs, and how this usage varies according to different forms of ownership. Among the seven HRM practices examined, free market selection (65\%) and performance-linked pay (70\%) were most often adopted by Chinese SMEs. Over fifty percent of the SMEs in the sample also encouraged employees' participation in decision making. HRM practices in the areas of training and development, performance evaluation and provision of social benefits were less frequently adopted by Chinese SMEs. The role of trade unions was also deemed to be limited within the SMEs examined (see Table 4).

The data in Table 4 also indicate how the use of HRM practices differs according to ownership. Clearly, domestic private-owned enterprises as well as foreign-related enterprises have adopted more of the innovative HRM practices, such as free market selection, performancebased pay, training and development, performance evaluation and participatory decision making, than state-related enterprises have. However, state-related enterprises were more likely to have provided social benefits to their employees than other types of enterprises were. The operational role of trade unions was evident in both state-owned and foreign related companies - this is consistent with the observations made from the earlier studies by Tsang (1994), Goodall and Warner (1997) and Zhu and Warner (2002) - but not so among collective and domestic private owned firms.

\section{$<$ Table 4 about here $>$}

\section{The effect of HRM practices on HRM outcomes}

Two hypotheses are tested in this research, with the first focusing on the effect of the use of HRM practices on HRM outcomes. As discussed in the previous section, factor analysis was first used to reduce the seven HRM practices into uncorrelated constructs, before these constructs were included as independent variables in logistic regression equations. From the factor analysis, three constructs were extracted. A three factor solution was indicated by the Scree plot, and about $82 \%$ of the variance was explained with this solution which is desirable (Stevens 1996). 
The rotated component matrix from this factor analysis is shown in Table 5. The first factor is highly correlated with the HRM practice variables such as provision of a social security scheme (SSS) and role of trade unions, and negatively correlated with the variable free market selection. Factor 2 is highly correlated with staff training and development and performance evaluation. The last factor (Factor 3) is highly correlated with performance-linked payment and employment involvement in decision-making, and moderately correlated with free market selection and performance evaluation.

\section{$<$ Table 5 about here>}

Factor 1 has been termed the 'Social Benefits' factor. It is widely accepted (eg. Tsang 1994; Goodall and Warner 1997) that the provision of social benefits commonly accompanies strong labour union influence. Further, it may also be difficult for Chinese companies to dismiss staff and replace them using free market selection if the union influence is strong (Bronars et al. 1994).

Factor 2 has been named the 'Staff Development' factor. In many firms, performance evaluation leads to the development of staff training and development programs (Clark and Seward 2000, p. 261). According to Pinnington and Edwards (2000, pp. 162-177), decisions regarding staff training and development must be based on accurate results from performance appraisals. Moreover, it is likely that firms oriented towards using performance evaluation will also have the wherewithal to conduct staff training and development activities. Therefore, it is not surprising that these two variables are highly correlated.

Factor 3 loads most highly on the HRM practices relating to performance-based pay and employees' involvement in decision-making, and has moderate loadings on free market selection and performance evaluation. These four HRM practices have only been introduced to Chinese enterprises since the economic reform. The main intention of these practices is to motivate individuals and groups within enterprises, especially state-owned firms, to enhance productivity (Benson and Zhu 1999). Motivational theories such as Maslow’s (1954) hierarchy of needs and Herzberg's (1989) motivator-hygiene factors support the notion of adopting performance-based pay, and job design to enlarge employee participation in decision-making, so as to better motivate employees to achieve organisational goals. Therefore, Factor 3 is labeled the 
'Motivation' factor as it combines elements of HRM practices which stress motivating employees to achieve better HRM outcomes and firm performance.

Central to testing the first hypothesis is understanding whether these three HRM practice factors have led to better HRM outcomes. Logistic regression analysis is used to test the effect of these factors on four HRM outcomes (staff turnover, congruence, competency and commitment), with the results presented in Table 6. Control variables were also included in the regressions, relating to firm size, industry category, form of ownership, use of technology, years of establishment and location of the firm. Each of the models had very good explanatory power, as demonstrated by the Hosmer-Lemeshow test statistics and the McFadden $\mathrm{R}^{2}$ values. The chisquare values indicated that Models 2-4 are significant overall. The first Model related to staff turnover is marginally insignificant; however when several of the insignificant coefficients are removed, the model is significant at conventional levels.

In terms of the three HRM practice factors, the results in Table 6 indicate that the 'Motivation' factor has a significant impact on all four HRM outcomes. The 'Social Benefits' factor is significantly and negatively related to two HRM outcomes (congruence and commitment), and the 'Staff Development' factor is insignificant in all models. This indicates that some HRM practices, specifically those related to the factor motivation (performance linked pay, employee involvement in decision making, free market selection and performance evaluation) lead to improved HRM outcomes. However, other HRM practices have no effect on HRM outcomes (ie those related to staff development) or lead to lower HRM outcomes (ie social benefits, role of trade unions).

For the control variables, those relating to the different forms of enterprise ownership were the most frequently significant. State related enterprises ceterus paribus had better HRM outcomes than domestic privately-owned enterprises for each of the four outcomes. However, for turnover, congruence and competency, foreign related enterprises performed best across all of the forms of ownership, as indicated by the magnitude of the dummy variables. Foreign related enterprises did particularly well at generating staff congruence, with a coefficient of 5.144 in Model 2, compared to 2.303 for state related enterprises and 3.319 for collectively owned firms. Collectively owned firms did perform almost as well as foreign related firms for staff competency, with the dummy variable having a value of 3.520 compared to 3.639. 
When interpreting the coefficients for these dummy variables, it should be noted that they indicate the extent to which different ownership influences HRM outcomes, in addition to any effects the application of HRM practices would have. Thus, Model 1 indicates ceterus paribus that state related enterprises have less staff turnover than domestic private owned enterprises. However domestic owned enterprises are more likely to have payment linked to performance or employment involvement in decision making, which influence the motivation factor. The predicted outcome for any firm will depend on both their form of ownership and the HRM practices which they adopt.

A few other control variables were found to be significant predictors of HRM outcomes. Size of firms was positive significant in the staff turnover model. Manufacturing firms (-ve), use of technology (+ve) and being located in Fuzhou or Xiamen (+ve) were also found to be significant in the staff competency equation. However, the remaining control variables were insignificant.

\section{$<$ Table 6 about here $>$}

\section{The Effect of HRM Outcomes on Firm Performance}

While the use of HRM practices were demonstrated to influence HRM outcomes, it is also important to understand whether changes in HRM outcomes influences the performance of Chinese SMEs. This is the focus of the second hypothesis. The same methodological procedures that were used to test the first hypothesis are used here, with factor analysis initially applied to extract uncorrelated constructs which are then included in logistic regression equations.

The results from the factor analysis are shown in Table 7. A two factor solution was supported both by the Scree plot and total variance explained (84.6\%). Three HRM outcomes namely staff turnover, staff congruence and staff commitment - are highly correlated with the first factor and the second factor is highly correlated with staff competence and moderately correlated with staff turnover. The first factor is named the 'Staff Commitment' factor as staff commitment is the variable with the highest loading. Also, staff commitment can be seen, to some degree, as being representative of the other variables. High staff congruence may result in higher staff commitment, while higher staff commitment may in turn lead to lower levels of staff 
turnover (Mowday et al. 1982; Beer et al. 1984; Guest 1987; 1997; Guthrie 2001; Richard and Johnson 2004; Gollan 2005).

\section{$<$ Table 7 about here $>$}

The second factor is called the 'Staff Competency' factor for two reasons. First, the variable staff competency (0.958) clearly has the highest loading for this factor, with staff turnover having only a moderate loading (0.439). Second, staff turnover is likely to be associated with staff competency as discussed in the literature. For instance some researchers (eg. Steel and Griffeth 1989; Khatri et al. 2001) have argued that the more competent employees are, the more likely they will leave current jobs and seek ones with better employment conditions in the labour market. This is particularly true in the Asian context where the labour market has a shortage of skilled workers and there are financial constraints for firms to provide employees with opportunities for further education and training (Khatri et al. 2001; Zheng and Stahl 2001). Other researchers (eg. Melvin 1996; Wai and Robinson 1998; Kamis 1999; Shah et al. 2001), however, have claimed that staff turnover can be reduced when competency development is guaranteed. Studies of employee commitment and employee turnover also support the argument that the main cause of employee turnover may not necessarily be the level of staff competency, but organisational design (Mobley 1982; Mowday et al. 1982; Simons 2005; Hiltrop 2005). If the organisational design allows career advancement and competency development, employees are less likely to leave current jobs (Conway 2004). Therefore, staff competency achieved through training and development is potentially linked with a lower level of staff turnover.

The logistic regression results showing the effect of the two HRM outcome constructs on SME performance are presented in Table 8. Three equations are presented, showing the contribution of HRM outcomes to increasing sales, marketing competitiveness and expected growth. Similar to the previous regression equations, various control variables are included relating to number of employees, industry category, form of ownership, years of establishment and the use of technology. Each of the equations is significant overall and has high levels of explanatory power.

The results demonstrate that the 'Staff Commitment' factor is significantly related to all three enterprise performance indicators. The 'Staff Commitment' factor contributes almost twice as much to increasing firms' sales and production $(\beta=1.898, p<0.01)$ than to expectations of increasing market competitiveness $(\beta=0.852, p<0.01)$ and growth potential $(\beta=0.952, p<0.01)$. 
In contrast, the 'Staff Competency' factor is only related to increasing sales and expected growth. In addition, the magnitude of the coefficients is smaller and both have only a marginally significant relationship with firms' sales and production $(\beta=0.719, p<0.1)$ and expected growth $(\beta=0.537, p<0.1)$. These results provide support for the second hypothesis, that better HRM outcomes achieved by Chinese SMEs will lead to better enterprise performance.

\section{$<$ Table 8 about here $>$}

Several control variables are significant predictors of firm performance. The models indicate that relative to the uncategorised firms, business-trading firms are expecting lower sales and production growth and market competitiveness, and IT-related firms also expect declines in market competitiveness. The application of technology in Chinese SMEs is negatively related with expectations of firms' increasing sales and production, implying that application of HRM practices is perhaps more effective than that of technology for achieving better enterprise performance. Unlike with the HRM outcomes, enterprise ownership was insignificantly related to enterprise performance. This is consistent with the conclusion drawn from Zhu and Dowling (1994; 2002) and Zhu (1997), claiming that ownership may have an association to what kinds of HRM practices being adopted, but has no direct impact on firm performance.

\section{Discussion and Recommendations for HRM Practice in Chinese SMEs}

The purpose of this research has been to investigate the extent of HRM practices among the Chinese SMEs and to examine whether the use of HRM practices influences HRM outcomes and the SME performance in China. Two hypotheses were tested, the first focusing on whether the use of HRM practices influences HRM outcomes, while the second focused on whether HRM outcomes influence the performance of Chinese SMEs.

The statistical results indicate that SMEs in China largely emphasise HRM practices in the areas of strategic selection and recruitment, performance-based remuneration, employee involvement in decision-making. They also pay some attention to performance evaluation and training and skill development, but not to a greater extent. The results are fairly consistent with the findings in earlier studies of HRM practices in SMEs in US and UK, whereby small firms tend to focus on selective staffing practices (eg. Terpstra \& Rozell 1993), performance-based compensation and benefits packages (Rowden 2001) and empowerment via encouraging 
employee participation in decision-making (Wyer and Mason 1999), but not have sufficient performance appraisal and training in place (Hornsby and Kuratko 1990; 2003; Matlay 1997).

The results also show that foreign-related firms are more likely in the position of adopting more HRM practices than those in the collective and state-related companies (Zhu and Warner 2004; Ahlstrom et al. 2005). This is similar to the results found in Audea, Teo and Crawford's (2005) study of HRM practices in Philippines, whereby foreign-owned firms tend to show a slightly higher level of adoption of HRM practices.

The results from the statistical analyses generally support the first hypothesis. That is, HRM has a positive impact on employee behaviour in Chinese SMEs. Specifically, the application of HRM practices can help achieve better HRM outcomes, which is reflected in lower levels of staff turnover and higher levels of staff commitment, competency and congruence (Beer et al. 1984; Guest 1987; 1997). However, it was found in this study that not all of the HRM practices proposed in the first hypothesis contribute positively to enhancing HRM outcomes. In fact, the 'Social Benefit' factor, which includes the practices of provision of social security schemes and the exercise of trade union power, was negatively related to all HRM outcomes.

It appears that the provision of social benefits in Chinese industrial enterprises is not an effective way of improving work performance. This is consistent with the findings from the earlier studies of Chinese enterprises whereby the provision of social benefits was seen to be associated with the old regime and was not deemed a beneficial element in performance management (see Goodall and Warner 1999). However, the results are different from the studies drawn from the other contexts. For example, in Taiwan, Chang and Chen (2002) found, from their study of 197 Taiwanese high-tech firms, that provision of more comprehensive a firm's benefits significantly increases the effect on firm performance. A stronger entitlement mentality of Mainland Chinese employees also create headache for Taiwanese, Singaporean and Hong Kong businesspeople to manage their HR in China as what they take benefits as motivational factor to enhance performance, their Chinese employees would take it as 'Iron Rice Bowl' (Tsang 1994; Goodall and Warner 1997; Lewis 2003; Chow 2004b).

Perspectives on the role and effect of trade unions in China are diverse. Some argue that they are a means of encouraging employee participation in decision making and will, therefore, enhance productivity (Bronars et al. 1994; Ji 1998; Audea et al. 2005). Others found that trade unions have been used primarily as the Party's policy instrument, not entirely representing 
workers’ interests (Laaksonnen 1988; Tsang 1994), and newly established firms tend to be less focused on maximizing the role of trade unions (Zhu and Dowling 1994; 2000). The results in this paper indicate that HRM outcomes are not generated from increased provision of social benefits or the action of trade unions. Instead, other HRM practices, such as strategic selection of staff, incentive payment and performance evaluation led to better HRM outcomes.

Interestingly, the 'Staff Development' factor, which combines the HRM practices of performance evaluation and training and development, was found to have no significant impact on HRM outcomes. This is contradictory to the earlier findings from studying the link of performance evaluation to firm performance in other contexts. For example, both Chang \& Chen (2002) and Wan, Ong and Kok (2002) found that there is a significant relationship between performance appraisal to firm financial performance in Taiwanese high-tech firms and MNCs in Singapore. Bartel (1994; 2004) showed a positive relationship between training and productivity gains, between bank financial performance and employees' satisfaction with the quality of performance evaluation and feedbacks in US organisations. The reason of the differences might be due to firm size and nature of SMEs studied, as the previous studies tend to examine HRM practices in multinational, high-tech companies or in large banking industry. As noted by Kerr and McDougall (1999), because of cost and time consciousness, small firms may not take performance evaluation and training seriously. The evidence from China is that only limited forms of performance evaluation have been introduced to large industrial enterprises (Warner 1993; Goodall and Warner 1999; Zhu and Dowling 2000), with much less being introduced in small and medium sized firms. Furthermore, a limited supply of quality human resources in Chinese labour markets means that to fully complete the training of low-skilled employees would take a longer period of time. Therefore, current training and development programs exhibited in the sample might not be effective in skilling the SME workforce. That is, it is possible that many of the existing training schemes may be relatively ineffective. It is held that these combined effects may go some way to explain why the 'Staff Development' factor in this study does not have a significant effect on HRM outcomes.

The second hypothesis, which proposed that better HRM outcomes achieved from the practice of HRM would lead to better enterprise performance, is also supported by the regression results. The study clearly indicated that a high level of employee commitment has a positive impact on firm performance. Employee competency also contributed to both sales and expected growth, although the contribution was less substantial, and the competency variable tended to be less significant in the regression equations. 
The employee commitment factor in this study summarised three main HRM outcome variables: staff turnover, staff commitment and staff congruence. Previous research has indicated that employee commitment tends to be associated with job satisfaction (eg. Cotton et al. 1988; Wagner 1994; Zhu and Dowling 1998; Bae \& Lawler 2000; Guthrie 2001). It has the effect of motivating staff to improve their work performance (Huselid 1995). The results of this study illustrate that employee commitment is also closely associated with Chinese SME performance.

Consistent with the results shown in Huselid's (1995) study, the staff competency factor contributed to SME performance. However, competency was shown to matter less than commitment. This is an important finding as most of the companies in Huselid's (1995) study were large, and would have the capacity to emphasise training and development more than SMEs. Training can be costly. That is why Chinese SMEs in the current study may be reluctant to provide training and staff development programs (note that only $34 \%$ of firms in this sample engaged in training and development). Instead, they may focus more on retention strategies to foster employee commitment, which is evident in the summary statistics for this study (see also Kerr and McDougall 1999). Nevertheless, this does not mean that skill development is not important for the development of SMEs. McLarty (1999), especially, recommended that SME managers should focus on building and developing a more effective skill base. He suggested that SMEs should not just look for conventional entrepreneurial skills, but also develop and maintain mature, competent and skilled-employees (McLarty 1999, p.110).

Perhaps training alone may not help enhance work performance. It appears to be more effective when included with other HRM practices. As recommended by Becker and Huselid (1999), integrated HRM practices could produce a greater source of competitive advantage because of synergies between practices. Similarly, Lawson and Hepps (2001) highlighted the significance of using human capital as a competitive asset at Wells Fargo. They emphasised that investing in human capital must be combined with specific, integrated bundles of HRM strategies in order to influence customer loyalty, enhance employee commitment and affect the bottom line (Lawson and Hepps 2001, p. 43).

The paradox of training (including management training) in SMEs was further elaborated by Marshall et al. (1995), Matlay (1997) and Wong et al. (1997). Although their studies were all based in the UK, the finding of an insignificant correlation between training and firm 
performance (see also Westhead and Storey 1996) is consistent with the current study. This indicates that purely focusing on increasing staff competency via training and development may not necessarily help firm performance. Rather, practices of training and development - in conjunction with other HRM practices - may have greater effects on firm performance (Becker and Huselid 1999; Lawson and Hepps 2001).

Therefore, the findings from this study suggest that SMEs should place greater emphasis on staff commitment than on staff competency to improve the likelihood of achieving better firm performance. However, this does not suggest that staff competency achieved via training and skill improvement is not important for SMEs. Instead, it is recommended that employee skill improvement programs should be implemented well and they should be combined with other motivational instruments (Stajkovic and Luthans 2001) in order to promote behavioural changes, and in turn enhance performance.

\section{Future Research}

Although this study has made a significant contribution to the body of knowledge on HRM in SMEs, there exist limitations, such as the sample size, and the use of perceptual performance data. This may in part be overcome in future research by increasing the sample size, however the collection of objective measures of firm HRM behaviour and performance in China is likely to remain a difficulty in the short term.

As noted by Huselid and Becker (2000, p. 850), empirical studies of the HRM-firm performance relationship are still in a relatively nascent state in the literature. There is more work to be done in the area of examining HRM-firm performance in the context of Chinese SMEs. Future research could focus on extending the HRM variables that have been tested in this study. These might, for example, include different recruitment and remuneration practices. Ideally, longitudinal and objective performance data should be collected to measure the effectiveness of HRM practices over time, such as the one done by Guest et al. (2003) in the UK context. Despite the current difficulties in collecting such data from Chinese SMEs, it is possible that with the reforms taking place in China, company information may become readily accessible and transparent. 


\section{References}

Adler, P. (1988) ‘Managing Flexible Automation’ California Management Review, 30(3): 34-56.

Ahlstrom, D., Foley, S., Young, M. N., and Chan, E. S. (2005) 'Human Resource Strategies in Post WTO China', Thunderbird International Business Review, 47(3): 263-285.

Arthur, J. B. (1994) 'Effects of Human Resource Systems on Manufacturing Performance and Turnover', Academy of Management Journal, 37(3): 670-687.

Audea, T., Teo, S. T. T. and Crawford, J. (2005) 'HRM Professionals and Their Perceptions of HRM and Firm Performance in the Philippines', International Journal of Human Resource Management, 16(4): 532-552.

Bacon, N., Ackers, P., Storey, J. and Coates, D. (1996) 'It’s A Small world: Managing Human Resources in Small Business', International Journal of Human Resource Management, 7(1): 82-100.

Bae, J. S. and Lawler, J. J. (2000) 'Organisational and HRM Strategies in Korea: Impact on Firm Performance in an Emerging Economy’, Academy of Management Journal, 43(3): 502-517.

Barney, J. B. (1991) 'Firm Resources and Sustained Competitive Advantage', Journal of Management, 17(1): 99-120.

Bartel, A. P. (1994) 'Productivity Gains from the Implementation of Employee Training Programs’. Industrial Relations, 33(4): 411-425.

Bartel, A. P. (2004) 'Human Resource Management and Organisational Performance: Evidence from Retail Banking’, Industrial and Labour Relations Review 57(2): 181-195.

Becker, B. and Gerhart, B. (1996) 'The Impact of Human Resource Management on Organisational Performance: Progress and Prospects', Strategic Management Journal, 39: 779-801.

Becker, B. E. and Huselid, M.A. (1999) 'Overview: Strategic HRM in Five Leading Firms', Human Resource Management, 38: 287-301.

Becker, B. E., Huselid, M. A. and Ultrich, D. (2001) The HRM Scorecard: Linking People, Strategy and Performance, Harvard Business School Press.

Beer, M., Spector, B., Lawrence, P. R., Mills, D. Q. and Walton, R. E. (1984) Managing Human Assets: The Groundbreaking Harvard Business School Program, New York: The Free Press, Macmillan, Inc.

Begin, J. (1992) “Comparative Human Resource Management: A Systems Perspective”, International Journal of Human Resource Management, 3(3):18-44. 
Benson, J. and Zhu, Y. (1999) 'Markets, Firms and Workers in Chinese State-owned Enterprises’, Human Resource Management Journal, 9(4): 58-74.

Boxall, P. and Purcell, J. (2003) Strategy and Human Resource Management, Basingstoke: Palgrave McMillan.

Brand, M. J. and Bax, E. H. (2002) 'Strategic HRM for SMEs: Implications for Firms and Policy', Education and Training, 44(8/9): 451-463.

Brewster, C. (1993) 'Developing a 'European' Model of Human Resource Management', International Journal of Human Resource Management, 4(4): 765-784.

Bronars, S.G., Dear, D.R. and Tracey, J. (1994). 'The Effects of Unions on Firm Behaviour: An Empirical Analysis Using Firm Level Data’. Industrial Relations, 33(4): 426-452.

Brown, D. H. and Branine, M. (1996) 'Adaptive Personnel Management: Evidence of an Emerging Heterogeneity in China’s Foreign Trade Corporation', in D. H. Brown and R. Porter, eds, Management Issues in China: Domestic Enterprises, London: Routledge, Volume 1: 191-213.

Carroll, M., Marchington, M., Earnshaw, J. and Taylor, S. (1999) 'Recruitment in Small Firms: Processes, Methods and Problems’, Employee Relations, 21(3): 236-250.

Chang, P. L. and Chen, W. L. (2002) 'The Effect of Human Resource Management Practices on Firm Performance: Empirical Evidence from High-tech Firms in Taiwan', International Journal of Management, 19(4): 622-631

Child, J. (1994) Management in China during the Age of Reform, Cambridge University Press.

Child, J. (1995) 'Changes in the Structure and Prediction of Earning in Chinese State Enterprises During the Economic Reform', International Journal of Human Resource Management, 6(1): $1-30$.

China Statistical Yearbook (various years from 1990-2004).

Chow, Irene H. S. (2004a) 'Human Resource Management in China’s Township and Village Enterprises: Change and Development During the Economic Reform Era', Asia Pacific Journal of Human Resources, 42(3): 318-335.

Chow, Irene H. S. (2004b) 'The Impact of Institutional Context on Human Resource Management in Three Chinese Societies’, Employee Relations, 26(6): 626-642.

Clark, R. and Seward, J. (2000) Australian Human Resource Management: Framework and Practice, $3^{\text {rd }}$ Edition, Roseville: Irwin/McGraw-Hill.

Conway, E. (2004) 'Relating Career Stage to Attitudes toward HR Practices and Commitment: Evidence of Interaction Effects?' European Journal of Work and Organisational Psychology, 13(4): 17-32. 
Cotton, J. L., Vollrath, D. A., Froggatt, K. L., Sengnick-Hall, M. L. and Jennings, K. R. (1988) 'Employee Participation: Diverse Forms and Different Outcomes’, Academy of Management Review, 13: 8-22.

De Kok, J. and Uhlaner, L. M. (2001) 'Organisation Context and Human Resouce Management in the Small Firm', Small Business Economics, 17(4): 273-288.

Delaney, J. T. and Huselid, M. A. (1996) 'The Impact of Human Resource Management Practices on Perceptions of Organisational Performance', Academy of Management Journal, 39(4): 949-957.

Deshpande, S. P. and Golhar, D. Y. (1994) 'HRM Practices in Large and Small Manufacturing Firms: A Comparative Study’, Journal of Small Business Management, Milwaukee, 32(2): 4956.

Devanna, M. A., Fombrun, C. J. and Tichy, N. M. (1981), "Human Resource Management: A Strategic Approach”, Organisational Dynamics, Winter: 51-78.

Devanna, M. A., Fombrun, C. J. and Tichy, N. M. (1984) 'A Framework for Strategic Human Resource Management', Chapter 3 in Fombrun, C. J., Tichy, N. M. and Devanna, M. A., Strategic Human Resource Management, New York: John Wiley and Sons, pp. 33-56.

Ding, D., Fields D. and Akhtar, S. (1997) 'An Empirical Study of Human Resource Policies and Practices in Foreign-Invested Enterprises in China: the Case of Shenzhen Special Economic Zone', International Journal of Human Resource Management, 8(5): 595-613.

Dowling, P. J., Welch, D. E. and Schuler, R. S. (1999) International Human Resource Management: Managing People in a Multinational Context, $3^{\text {rd }}$ Edition, Cincinnati: SouthWestern College Publishing.

Golhar, D. Y. and Deshpande, S. P. (1997) 'HRM Practices in Large and Small Canadian Firms', Journal of Small Business Management, Milwaukee, 35(3): 30-38.

Gollan, P. J. (2005) 'High Involvement Management and Human Resource Sustainability” The Challenges and Opportunities', Asia Pacific Journal of Human Resources, 43(1): 18-37.

Goodall, K. and Warner, M. (1997) 'Human Resources in Sino-Foreign Joint Ventures: selected case studies in Shanghai, compared with Beijing',International Journal of Human Resource Management, 8(5): 569-594.

Goodall, K. and Warner, M. (1999) 'Enterprise Reform, Labour-Management Relations and Human Resource Management in a Multinational Context: Empirical Evidence from SinoForeign Joint Ventures', International Studies of Management and Organisation, 29(30: 2136.

Gospel, H. (1992) Markets, Firms and the Management of Labour in Modern Britain, Cambridge: Cambridge University Press. 
Gratton, L., Hope-Hailey, V., Stiles, P., and Truss, C. (1999) 'Linking Individual Performance to Business Strategy: The People Process Model', Human Resource Management, 38(1): 17-31.

Guest, D. E. (1987) 'Human Resource Management and Industrial Relations', Journal of Management Studies, 25(5): 503-521.

Guest, D. E. (1997) 'Human Resource Management and Performance: A Review and Research Agenda', International Journal of Human Resource Management 8(3): 263-276.

Guest, D., Michie, J., Conway, N. and Sheehan, M. (2003) 'Human Resource Management and Corporate Performance in the UK', British Journal of Industrial Relations, 41(2): 291-304.

Guthrie, J. P. (2001) 'High-Involvement Work Practices, Turnover, and Productivity: Evidence from New Zealand', Academy of Management Journal, 44(1): 180-190.

Hair, J. F. Jr., Anderson, R. E., Tatham, R. L. and Black, W. C. (1998) Multivariate Data Analysis, Fifth Edition, Prentice-Hall International, Inc.

Herzberg, F. (1962) 'New Approaches in Management Organisation and Job Design', Management and Organisational Behaviour Classics, edited by Matteson and Ivancevich (1989), pp. 229-237. The article was first published in Journal of Industrial Medicine, November, 1962.

Hiltrop, J. M. (2005) 'Creating HR Capability in High Performance Organisations’, Strategic Change, 14(3): 121-132.

Hornsby, J. and Kuratko, D. (1990) 'Human Resource Management in Small Business: Critical Issues for the 1990s', Journal of Small Business Management, July: 9-18.

Hornsby, J. and Kuratko, D. (2003) 'Human Resource Management in U.S. Small Businesses: A Replication and Extension', Journal of Developmental Entrepreneurship, 8(1):73-92.

Huselid, M. A. (1994) 'Documenting HR's Effect on Company Performance', HRM Magazine, 39(1): 79-84.

Huselid, M. A. (1995) 'The Impact of Human Resource Management Practices on Turnover, Productivity, and Corporate Financial Performance', Academy of Management Journal, 38(3): 635-670.

Huselid, M. A., Jackson, S. E. and Schuler, R. S. (1997) 'Technical and Strategic Human Resource Management Effectiveness as Determinants of Firm Performance', Academy of Management Journal, 40(1): 171-188.

Huselid, M. A. and Becker, B. E. (2000) 'Comments on 'Measurement Error in Research on Human Resources and Firm Performance: How Much Error is There and How Does It Influence Effect Size Estimates?' by Gerhart, Wright, McMahan and Snell', Personnel Psychology, 53: 835-854. 
Jackson, S. E. and Schuler, R. S. (1995) 'Understanding Human Resource Management in the Context of Organization and Their Environment'. Annual Review of Psychology, 46: 237-264. Ji, Y. (1998) China’s Enterprise Reform: Changing State/Society Relations after Mao, London: Routledge.

Kaman, V., McCarthy, A. M., Gulbro, R. D. and Tucker, M. L. (2001) 'Bureaucratic and High Commitment Human Resource Practices in Small Service Firms', Human Resource Planning, 24(1): 33-44.

Kamis, T. L. (1999) 'Education for the PRC Executive', China Business Review, July-August: 36-39.

Kerr, A. and McDougall, M. (1999) 'The Small Business of Developing People', International Small Business Journal, 17(2): 65-74.

Khatri, N., Chong, T. F. and Budhwar, P. (2001) 'Explaining Employee Turnover in an Asian Context', Human Resource Management Journal, 11(1): 54-74.

Kotey, B. and Sheridan, A. (2004) 'Changing HRM Practices with Firm Growth', Journal of Small Business and Enterprise Development, 11(4): 474-489.

Kotey, B. and Slade, P. (2005) 'Formal Human Resource Management Practices in Small Growing Firms’, Journal of Small Business Management, 43(1): 16-40

Laaksonnen, O. (1988) Management in China during and after Mao in Enterprises, Government and Party, Berlin: Walter de Gruyter.

Lähteenmäki, S., Storey, J. and Vanhala, S. (1998) 'HRM and Company Performance: the Use of Measurement and the Influence of Economic Cycles', Human Resource Management Journal, 8(2): 51-65.

Lawson, T. E. and Hepps, R. L. (2001) 'Measuring the Performance Impact of Human Resource Initiative', Human Resource Planning, 24(2): 36-44.

Lewis, P. (2003) 'New China-Old Ways? A Case Study of the Prospects for Implementing Human Resource Management Practices in a Chinese State-owned Enterprise', Employee Relations, 25(1): 42-60.

Li, J. (2003) 'Strategic Human Resource Management and MNEs' Performance in China', International Journal of Human Resource Management, 14(2): 157-173.

Lu, Y. and Bjorkman, I. (1997) 'HRM Practice in China-Western Joint Ventures: MNC Standardisation versus Localisation', International Journal of Human Resource Management, 8(5): 614-628.

MacDuffie, J. P. (1995) 'Human Resource Bundles and Manufacturing Performance: Organisation Logic and Flexible Production Systems in the World Auto Industry', Industrial and Labour Relations Review, 48: 197-221. 
McLarty, R. (1999) 'The Skills Development Needs of SMEs and Focus on Graduate Skills Application', Journal of Applied Management Studies, 8(1): 103-110.

Malhotra N. K., Hall, J., Shaw, M. and Crisp, M (1996) Marketing Research: An Applied Orientation, Sydney: Prentice Hall.

Marchington, M. and Grugulis, I. (2000) 'Best Practice Human Resource Management: Perfect Opportunity or Dangerous Illusions? International Journal of Human Resource Management, 11: $1104-1124$.

Marshall J. N., Alderman N., Wong, C. and Thwaites A (1995) 'The Impact of Management Training and Development on Small and Medium-Sized Enterprises', International Small Business Journal, 13(4): 73-85.

Maslow, A. H. (1954) Motivation and Personality, New York: Harper and Row Publisher.

Matlay, H. (1997) 'The Paradox of Training in the Small Business Sector of the British Economy’, Journal of Vocational Education and Training, 49(4): 573-588.

McEvoy, G. M. (1984) 'Small Business Personnel Practices', Journal of Small Business Management, October: 1-8.

Melvin, S. (1996) 'Training the Troops', China Business Review, March-April: 22-28.

Mobley, W. H. (1982) Employee Turnover: Causes, Consequences and Control, AddisonWesley.

Mowday, R. T., Porter, L. W. and Steers, R. M (1982) Employee-Organisation Linkages: The Psychology of Commitment, Absenteeism, and Turnover, New York: Academic Press.

Ng, T. C. and Siu, N. Y. M. (2004) 'Training and Enterprise Performance in Transition: Evidence From China’, International Journal of Human Resource Management, 15(5): 878894.

Ngo, H. Y., Turban, D., Lau, C. M. and Lai, S. Y. (1998) 'Human Resource Practices and Firm Performance of Multinational Corporation: Influence of Country of Origin', International Journal of Human Resource Management, 9(4): 632-652.

Paauwe, J. (2004) HRM and Performance: Achieving Long-Term Viability, New York: Oxford University Press.

Pfeffer, J. (1994) Competitive Advantage through Peopl,Boston: Harvard Business School Press. Pfeffer, J. (1998) The Human Equation: Building Profits by Putting People First, Boston: Harvard Business School Press.

Pinnington, A. and Edwards, T. (2000) Introduction to Human Resource Management. New York: Oxford University Press.

Pieper, R. (1990) Human Resource Management: An International Comparison, Berlin: Walter de Gruyter. 
Rainnie, A. (1989) Industrial Relations in Small Firms, London: Routledge.

Ram, M. (1991) 'The Dynamics of Workplace Relations in Small Firms', International Small Business Journal, 10(1): 44-53.

Richard, O. C. and Johnson, N. B. (2004) 'High Performance Work Practices and Human Resource Management Effectiveness: Substitutes or Complements', Journal of Business Strategies, 21(2): 133-148.

Rowden, R. W. (2002) 'High Performance and Human Resource Characteristics of Successful Small Manufacturing and Processing Companies’, Leadership and Organisation Development Journal, 23(2): 79-83.

Schuler, R. S. and Huber, V. L. (1993) Personnel and Human Resource Management, $5^{\text {th }}$ Edition, St. Paul, MN: West Publishing Co.

Schuler, R. S. (1997) 'Human Resource Management', in Warner, M., edited, Concise International Encyclopedia of Business and Management, London: International Thomson Business Press, pp. 243-263.

Shah, A., Sterrett, C., Chesser, J. and Wilmore, J. (2001) 'Meeting the Need for Employee Development in the $21^{\text {st }}$ Century', SAM Advanced Management Journal, 66(2): 22-28.

Simons, R. (2005) ‘Designing High-Performance Jobs’, Harvard Business Review, 83(7): 54-59.

Snell, S.A., Youndt, M.A. and Wright, P.M. (1996).’Establishing a Framework for Research in Strategic Human Research Management: Merging Resource Theory and Organisational Learning'. Research in Personnel and Human Resources Management, 14: 61-90

Stajkovic, A. D. and Luthans, F. (2001) 'Differential Effects of Incentive Motivators on Work Performance', Academy of Management Journal, 4(3): 580-590.

Stavrou, E. T. and Brewster, C. (2005) 'The Configurational Appraoch to Linking Strategic Human Resource Management Bundles with Business Performance: Myth or Reality?', Management Revue, 16(2): 186-201.

Steel, R. P. and Griffeth, R. W. (1989) 'The Elusive Relationship between Perceived Employment Opportunity and Turnover Behaviour: A Methodological or Conceptual Artifact', Journal of Applied Psychology, 74(6): 846-854.

Stevens, J. (1996) Applied Multivariate Statistics for the Social Sciences, $3^{\text {rd }}$ Edition, New Jersey: Lawrence Erlbaum.

Storey, J. (1992) Developments in the Management of Human Resource, Oxford: Blackwell.

Szamosi, L. T., Duxbury, L. and Higgins, C. (2004) 'Toward an Understanding of People Management Issues in SMEs: a South-Eastern European Perspective', Education and Training, London, 46(8/9): 444-465. 
Tabachnick, B. G. and Fidell, L. S. (2000), Using Multivariate Statistics, $4^{\text {th }}$ Edition, New York: Allyn and Bacon Inc.

Terpstra, D. e. and Rozell, E. J. (1993) 'The Relationship of Staffing Practices to Organisational Level Measures of Performance', Personnel Psychology, 46: 27-48.

Tsang, E. W. K. (1994) 'Human Resource Management Problems in Sino-Foreign Joint Ventures', International Journal of Manpower, 15(9/10): 4-21.

Ulrich, D. (1997) Human Resource Champions: the Next Agenda for Adding Value and Delivering Results, Boston: Harvard Business School Press.

Ulrich, D. (1998) 'A New Mandate for Human Resources’, Harvard Business Review, 76(1): 124-134.

Wagner, J. A. (1994) ‘Participation’s Effect on Performance and Satisfaction: A Reconsideration of Research Evidence’, Academy of Management Review, 19: 312-330.

Wai, C. T. and Robinson, C. D. (1998) 'Reducing Staff Turnover: A Case Study of Dialysis Facilities’, Health Care Management Review, 23(4): 21-42.

Wan, D., Ong, C. H. and Kok, V. (2002) 'Strategic Human Resource Management and Organisational Performance in Singapore', Compensation and Benefits Review, 34(4): 33-42.

Warner, M. (1993) 'Human Resource Management 'with Chinese Characteristics', International Journal of Human Resource Management, 4(1): 151-170.

Warner, M. (1997) 'Management-Labour Relations in the New Chinese Economy', Human Resource Management Journal, 7(4): 30-43.

Watson, R., Storey, D. J., Wynarczyk, P., Keasey, K. and Short, H. (1994) 'The Remuneration of Non-owner Managers in Small and Medium-sized UK Enterprises’, Journal of Management Studies, 31(4): 553-568.

Westhead, P. and Storey, D. (1996) 'Management Training and Small Firm Performance: Why is the Link So Weak?’, International Small Business Journal, 14(4): 13-24.

Wong, C., Marshall J. N., Alderman N. and Thwaites A (1997) 'Management Training in Small and Medium-Sized Enterprises: Methodological and Conceptual Issues', International Journal of Human Resource Management, 8(1): 44-65.

Wood, S. (1999). 'Human Resource Management and Performance'. International Journal of Management Review, 1(4): 367-413.

WorldBank (2005)

http://devdata.worldbank.org/external/CPProfile.asp?SelectedCountry=CHN\&CCODE=CHN $\& \mathrm{CNAME}=\mathrm{China} \& \mathrm{PTYPE}=\mathrm{CP}$

Wright, P. M. and McMahan, G. C. (1992) 'Theoretical Perspectives for Strategic Human Resource Management', Journal of Management, 18: 295-320. 
Wright, P. M., Mitsuhashi, H. and Chua, R. S. K. (1998) 'HRM in Multinationals’ Operations in China: Building Human Capital and Organisational Capability', Asia Pacific Journal of Human Resources, 36(2): 3-14.

Wright, P. M., Gardner, T. M., Moynihan, L. M. and Allen, M. R. (2005) 'The Relationship between HR Practices and Firm Performance: Examining Causal Order', Personnel Psychology, 58(2): 409-447.

Wyer, P. and Mason, J. (1999) 'Empowerment in Small Businesses', Participation and Empowerment: An International Journal, 7(7): 180-193.

Youndt, M. A., Snell, S. A., Dean, J. W. and Lepak, D. P. (1996) 'Human Resource Management, Manufacturing Strategy and Firm Performance', Academy of Management Journal, 39: 836-866.

Zheng, C. and Stahl, C. (2001) Skill Shortages, Training Needs and Human Resource Development Strategies of Multinational Companies in APEC Member Economies, Singapore: APEC Secretariat.

Zhu, Cherrie J. H. (1997) 'Human Resource Development in China during the Transition to a New Economic System', Asia Pacific Journal of Human Resource, 35(3): 19-44.

Zhu, C. J. H. and Dowling, P. J. (1994) 'The Impact of the Economic System upon Human Resource Management Practices in China', Human Resource Planning, 17(4): 1-21.

Zhu, C. J. H. and Dowling, P. J. (2000) 'Managing People during Economic Transition: The Development of HRM Practices in China', Asia Pacific Journal of Human Resource, 38(2): 84-106.

Zhu, C. J. H. and Dowling, P. J. (2002) 'Staffing Practices in Transition: Some Empirical Evidence in China', International Journal of Human Resource Management, 13: 569-597.

Zhu, Cherrie J. H., Cooper, B., De Cieri, H. and Dowling, P. J. (2005) ‘A Problematic Transition to a Strategic Role: Human Resource Management in Industrial Enterprises in China', International Journal of Human Resource Management, 16(4): 513-531.

Zhu, Y. and Warner, M. (2002) 'Human Resource Management in China's 'Frontier' Special Economic Zone: A Study of Selected Enterprises on Hainan Island', International Journal of Employment Studies, 10(1): 75-104.

Zhu, Y. and Warner, M. (2004) 'Changing Patterns of Human Resource Management in Contemporary China: WTO Accession and Enterprise Response', Industrial Relations Journal, 35(4): 311-328. 
Table 1. Specific HRM and Performance Indicators in Five HRM Models

\begin{tabular}{|c|c|c|c|}
\hline $\begin{array}{c}\text { Authors/ } \\
\text { Models }\end{array}$ & HRM practice variables & HRM outcome variables & Performance indicators \\
\hline $\begin{array}{l}\text { Beer et al. } \\
\text { (1984) }\end{array}$ & $\begin{array}{l}\text { Broadly defined as four HRM policy } \\
\text { choices: } \\
\text { - } \quad \text { Employee influence } \\
\text { - } \quad \text { HRM flow } \\
\text { - } \quad \text { Reward systems } \\
\text { - } \quad \text { work system }\end{array}$ & 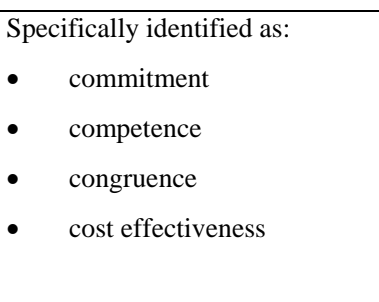 & $\begin{array}{l}\text { Broadly defined as organisational } \\
\text { effectiveness, individual and social } \\
\text { well-being }\end{array}$ \\
\hline $\begin{array}{l}\text { Devanna } \\
\text { et al. (1984) }\end{array}$ & $\begin{array}{l}\text { Specifically examined four areas of } \\
\text { HRM practices: } \\
\text { - } \quad \text { selection } \\
\text { - } \quad \text { rewards } \\
\text { - } \quad \text { appraisal } \\
\text { - } \\
\text { development }\end{array}$ & No indicators in this respect & Broadly defined as performance \\
\hline Guest (1987) & \begin{tabular}{ll}
\multicolumn{2}{l}{ Specially examined HRM polices on } \\
- & job design \\
- & recruitment/selection \\
- & appraisal \\
- & training \& development \\
- & reward systems \\
- & communication \\
- & manpower flows \\
- & change management
\end{tabular} & 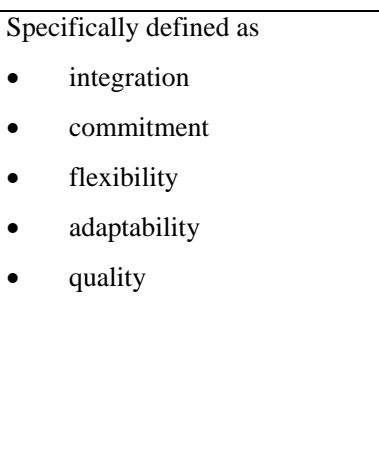 & \begin{tabular}{ll}
\multicolumn{2}{l}{ Specifically defined as } \\
- & high job performance \\
- & high problem solving skills \\
- & high cost-effectiveness \\
- & low absence \\
- & low staff turnover \\
- & low grievance
\end{tabular} \\
\hline $\begin{array}{l}\text { Schuler \& } \\
\text { Huber (1993); } \\
\text { Schuler, } \\
\text { (1997) }\end{array}$ & 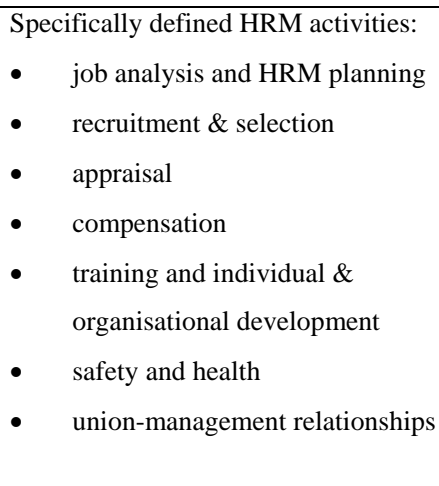 & No specific indicators & $\begin{array}{l}\text { General } \\
\text { - } \quad \text { attract, retain, motivate } \\
\text { Specific } \\
\text { - } \quad \text { productivity, quality of work life, } \\
\text { legal compliance, gaining } \\
\text { competitive advantage, workforce } \\
\text { flexibility } \\
\text { Bottom line } \\
\text { - } \quad \text { survival, competitiveness, } \\
\text { growth., profitability, adaptability }\end{array}$ \\
\hline Guest (1997) & \begin{tabular}{ll}
\multicolumn{2}{l}{ Specifically HRM practices cover: } \\
- & selection \\
- & training \\
- & appraisal \\
- & rewards \\
- & job design \\
- & involvement \\
- & status and security
\end{tabular} & \begin{tabular}{l}
\multicolumn{2}{l}{ Specifically defined as: } \\
- $\quad$ employee commitment \\
- $\quad$ quality \\
- $\quad$ flexibility
\end{tabular} & \begin{tabular}{ll}
\multicolumn{2}{l}{ Specifically defined as } \\
- & high productivity \\
- & high quality \\
- & high innovation \\
- & low absence \\
- & low labour turnover \\
- & low conflict \\
- & less customer complaints
\end{tabular} \\
\hline
\end{tabular}


Table 2

A Summary of Empirical Studies on the Effects of a 'Bundle' of HRM Practices on Performance

\begin{tabular}{|c|c|c|c|c|}
\hline Authors & HRM Practices & HRM Outcomes & Performance Indicators & Size of firms selected for study \\
\hline $\begin{array}{l}\text { Arthur } \\
(1994)\end{array}$ & $\begin{array}{ll}\text { - } & \text { Decentralised decision-making } \\
\text { - } & \text { Employee participation program } \\
\text { - } & \text { General training } \\
\text { - } & \text { Skill level, supervision } \\
\text { - } & \text { Sue process } \\
\text { - } & \text { Wage level } \\
\text { - } & \text { Benefits and bonus } \\
\end{array}$ & $\begin{array}{ll}\text { - } & \text { Control system } \\
\text { - } & \text { Commitment } \\
\text { system }\end{array}$ & $\begin{array}{ll}\checkmark & \text { Employee turnover } \\
\checkmark & \text { Scrap rate } \\
\checkmark & \text { Labour hours }\end{array}$ & 30 American steel minimills \\
\hline $\begin{array}{l}\text { McDuffie } \\
\text { (1995) }\end{array}$ & $\begin{array}{ll}- & \text { Hiring criteria } \\
\text { - } & \text { Contingent compensation } \\
\text { - } & \text { Status differentiation } \\
\text { - } & \text { Training } \\
\end{array}$ & $\begin{array}{l}\text { No outcome } \\
\text { indicators }\end{array}$ & $\begin{array}{ll}\checkmark & \text { Labour productivity (the hours of } \\
\text { actual working effort required to } \\
\text { build a vehicle) } \\
\checkmark \\
\text { Quality (the number of defects per } \\
100 \text { vehicles) }\end{array}$ & $\begin{array}{l}62 \text { international large automobile } \\
\text { manufacturing plants }\end{array}$ \\
\hline $\begin{array}{l}\text { Huselid } \\
\text { (1995) }\end{array}$ & $\begin{array}{ll}\text { - } & \text { Selection with employment test prior to hiring } \\
\text { - } & \text { Selection for non-entry level jobs } \\
\text { - } & \text { Performance appraisal as determinant for compensation } \\
\text { - } & \text { Formal performance appraisal received by the workforce } \\
\text { - } & \text { Incentive compensation } \\
\text { - } & \text { Job design } \\
\text { - } & \text { Grievance procedures } \\
\text { - } & \text { Information sharing } \\
\text { - } & \text { Labour-management participation } \\
\text { - } & \text { Intensity of the firm's recruiting efforts (selection ratio) } \\
\text { - } & \text { Average number of hours of training per employee per year } \\
\text { - } & \text { Promotion criteria (seniority versus merit) } \\
\end{array}$ & $\begin{array}{ll}\text { Employee } \\
\text { turnover } \\
\text { - } & \text { Productivity } \\
\text { Employment } \\
\text { skills and } \\
\text { organisational } \\
\text { structure } \\
\text { - Employee } \\
\text { motivation }\end{array}$ & $\begin{array}{ll}\checkmark & \text { Accounting profits (GRATE and } \\
\text { price-cost margin) } \\
\checkmark & \text { Economic profits (logarithm of } \\
\text { Tobin's q and total shareholder } \\
\text { return) }\end{array}$ & $\begin{array}{l}495 \text { American firms with over } 100 \\
\text { employees }\end{array}$ \\
\hline $\begin{array}{l}\text { Delaney } \\
\text { and Huselid } \\
\text { (1996) }\end{array}$ & $\begin{array}{ll}\text { - } & \text { Selectivity in hiring } \\
\text { - } & \text { Employee training } \\
\text { - } & \text { Incentive compensation } \\
\text { - } & \text { Grievance procedures } \\
\text { - } & \text { Job or work structure } \\
\text { - } & \text { Internal labor market for employee promotions } \\
\text { - } & \text { Vertical hierarchy } \\
\end{array}$ & $\begin{array}{l}\text { No indicators of } \\
\text { outcomes }\end{array}$ & 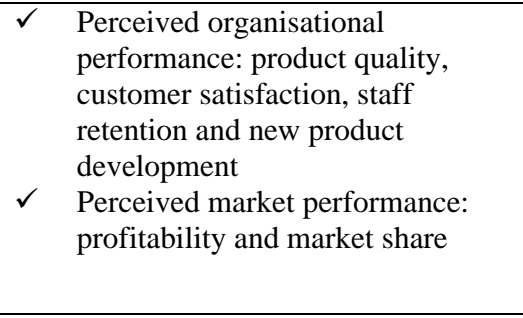 & 727 US organisations \\
\hline $\begin{array}{l}\text { Youndt et } \\
\text { al. (1996) }\end{array}$ & $\begin{array}{ll}- & \text { Staffing } \\
\text { - } & \text { Training } \\
\text { - } & \text { Performance appraisal } \\
\text { - } & \text { Compensation }\end{array}$ & $\begin{array}{ll}\text { - } & \text { Administrative } \\
\text { - } & \text { HR system } \\
\text { Human-capital- } \\
\text { enhancing HR } \\
\text { system }\end{array}$ & $\begin{array}{ll}\checkmark & \text { Machine efficiency } \\
\checkmark & \text { Customer alignment } \\
\checkmark & \text { Employee productivity }\end{array}$ & 97 US manufacturing plants \\
\hline
\end{tabular}




\begin{tabular}{|c|c|c|c|c|}
\hline $\begin{array}{l}\text { Lähteenmä } \\
\text { ki } \\
\text { et al. } \\
\text { (1998) }\end{array}$ & $\begin{array}{ll} & \text { HR planning span } \\
- & \text { HR development span } \\
- & \text { Relative proportion of HRM investment } \\
- & \text { Evaluation of the significant of HRM investment } \\
- & \text { Estimates of importance of management involvement in HRM } \\
- & \text { Career planning } \\
- & \text { Organisational status of the person in charge of HRM } \\
- & \text { Strategic role of HR as evaluated by HR manager } \\
- & \text { Integration of personnel policies with competitive strategy } \\
- & \text { HRM awareness } \\
- & \text { HRM goals }\end{array}$ & & 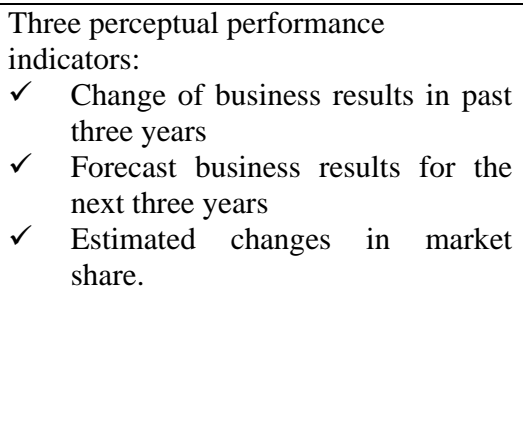 & $\begin{array}{l}428 \text { small (with 10-49 employees), } \\
\text { medium (50-499) and large (>500) } \\
\text { Finnish companies }\end{array}$ \\
\hline $\begin{array}{l}\text { Ngo et al. } \\
\text { (1998) }\end{array}$ & $\begin{array}{ll}25 & \text { items of HRM practices factored into four categories: } \\
\text { - } & \text { Structural training and development } \\
\text { - } & \text { Retention-oriented compensation } \\
\text { - } & \text { Seniority-based compensation } \\
& \text { Diversity } \\
\end{array}$ & $\begin{array}{ll}\text { - } & \text { Employees } \\
\text { satisfaction } \\
\text { Employees } \\
\text { retention } \\
\text { (inherent as HR } \\
\text { outcomes) } \\
\end{array}$ & $\begin{array}{ll}\text { Perceptual firm performance in the } \\
\text { areas of } \\
\checkmark & \text { Sales } \\
\checkmark & \text { Net profit } \\
\checkmark & \text { Development of new } \\
& \text { products/services } \\
\end{array}$ & $\begin{array}{l}332 \text { Hong Kong-based multinational } \\
\text { companies }\end{array}$ \\
\hline $\begin{array}{l}\text { Guthrie } \\
\text { (2001) }\end{array}$ & 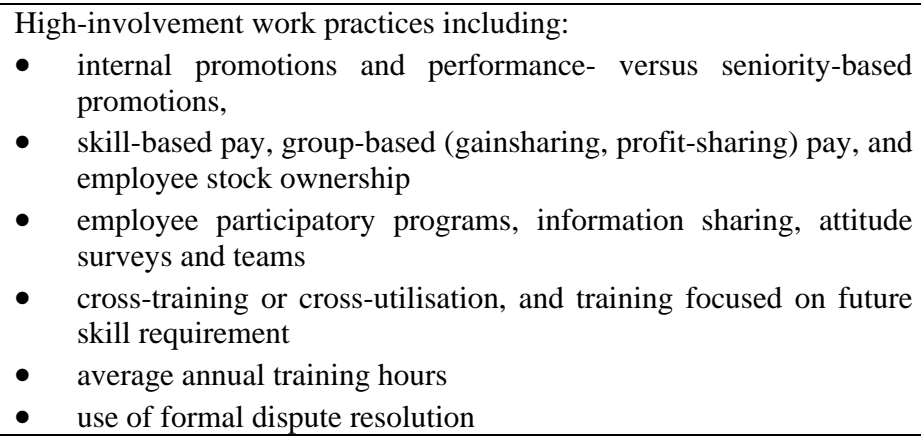 & $\begin{array}{ll} & \text { Employee } \\
\text { retention } \\
\text { (measured by } \\
\text { annual turnover) }\end{array}$ & $\begin{array}{l}\text { Productivity (calculated by log of } \\
\text { sales per employee) }\end{array}$ & $\begin{array}{l}164 \text { New Zealand companies with } \\
\text { more than } 100 \text { employees }\end{array}$ \\
\hline $\begin{array}{l}\text { Chang and } \\
\text { Chen } 2002\end{array}$ & $\begin{array}{ll}\text { - } & \text { training and development } \\
\text { - } & \text { teamwork } \\
\text { - } & \text { benefits } \\
\text { - } & \text { human resource planning } \\
\text { - } & \text { employment security } \\
\end{array}$ & $\begin{array}{ll}\text { employee } \\
\text { turnover }\end{array}$ & $\begin{array}{ll}\checkmark & \text { employee productivity }\end{array}$ & 62 Taiwanese high-tech companies \\
\hline $\begin{array}{l}\text { Stavrou and } \\
\text { Brewster } \\
2005\end{array}$ & $\begin{array}{ll}\text { - } & \text { training and career development bundle } \\
\text { - } & \text { pay for performance bundle (incl. profit sharing, merit-pay, share- } \\
\text { - } & \text { options, group bonues) } \\
\text { - } & \text { Joider-jobs bundle } \\
\text { - } & \text { Communication on organization of work bundle }\end{array}$ & $\begin{array}{l}\text { - No HR outcomes } \\
\text { indicator }\end{array}$ & $\begin{array}{ll}\text { Business performance measured in a } \\
\text { composite of } \\
\checkmark & \text { Profitability } \\
\checkmark & \text { Productivity and } \\
\checkmark & \text { Service Quality }\end{array}$ & $\begin{array}{l}3702 \text { business from } 15 \mathrm{EU} \text { member } \\
\text { states }\end{array}$ \\
\hline
\end{tabular}


Figure 1. A Conceptual Model of HRM and SME Performance in China

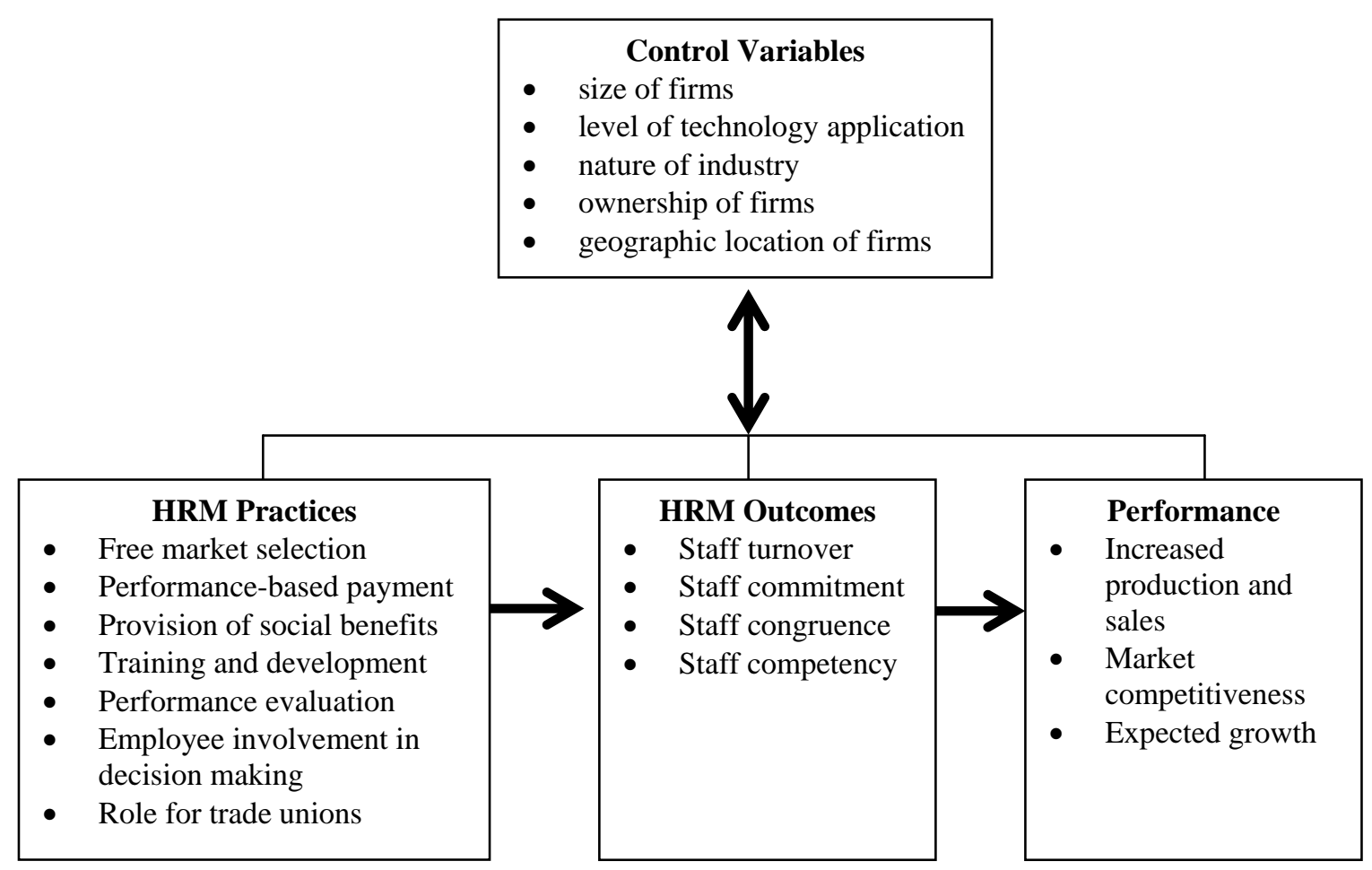


Zheng et al. 2006/7 - International Journal of Human Resource Management - in press

Table 3. Sample - City Distribution

\begin{tabular}{|l|c|c|}
\hline City & Interviews conducted & Cases used in Analysis \\
\hline Beijing & 3 & 3 \\
\hline Fuzhou & 13 & 11 \\
\hline Guangzhou & 12 & 2 \\
\hline Hanzhou & 5 & 8 \\
\hline Kunming & 8 & 21 \\
\hline Nanning & 21 & 5 \\
\hline Shanghai & 5 & 4 \\
\hline Shenzhen & 6 & 3 \\
\hline Tianjin & 4 & $\mathbf{7 4}$ \\
\hline Xiamen & 3 & $\mathbf{8 0}$ \\
\hline Total & & 6 \\
\hline
\end{tabular}


Table 4. HRM Practices amongst Chinese SMEs with Different Ownership

\begin{tabular}{|c|c|c|c|c|c|c|c|c|c|c|}
\hline \multirow{3}{*}{$\begin{array}{c}\text { HRM Practices } \\
\text { Free market selection }\end{array}$} & \multicolumn{10}{|c|}{ Enterprise Ownership } \\
\hline & \multicolumn{2}{|c|}{ State-related } & \multicolumn{2}{|c|}{ Foreign-related } & \multicolumn{2}{|c|}{$\begin{array}{l}\text { Collective- } \\
\text { related }\end{array}$} & \multicolumn{2}{|c|}{$\begin{array}{c}\text { Domestic } \\
\text { private-owned }\end{array}$} & \multicolumn{2}{|c|}{$\begin{array}{c}\text { Total number } \\
\text { of firms that } \\
\text { have fully } \\
\text { adopted the } \\
\text { practices }\end{array}$} \\
\hline & 9 & $36 \%$ & 9 & $56 \%$ & 8 & $73 \%$ & 22 & $100 \%$ & 48 & $65 \%$ \\
\hline Performance-linked payment & 15 & $60 \%$ & 10 & $63 \%$ & 7 & $64 \%$ & 20 & $91 \%$ & 52 & $70 \%$ \\
\hline Provision of social security scheme & 17 & $68 \%$ & 6 & $38 \%$ & 1 & $9 \%$ & 3 & $14 \%$ & 27 & $36 \%$ \\
\hline Training and development & 6 & $24 \%$ & 9 & $56 \%$ & 4 & $36 \%$ & 6 & $27 \%$ & 25 & $34 \%$ \\
\hline Performance evaluation & 4 & $16 \%$ & 9 & $56 \%$ & 4 & $36 \%$ & 6 & $27 \%$ & 23 & $31 \%$ \\
\hline Participatory decision-making & 9 & $36 \%$ & 10 & $63 \%$ & 5 & $45 \%$ & 14 & $64 \%$ & 38 & $51 \%$ \\
\hline Operational role of trade unions & 10 & $40 \%$ & 5 & $31 \%$ & 0 & $0 \%$ & 0 & $0 \%$ & 17 & $23 \%$ \\
\hline Total firms number & 25 & $100 \%$ & 16 & $100 \%$ & 11 & $100 \%$ & 22 & $100 \%$ & 74 & $100 \%$ \\
\hline
\end{tabular}


Table 5. Rotated Component Matrix for HRM Practice and HRM Outcome Variables

\begin{tabular}{|l|c|c|c|}
\hline \multicolumn{3}{|c|}{ Rotated Component Matrix } \\
\hline HRM Practice Variables & Social benefits & $\begin{array}{c}\text { Staff } \\
\text { development }\end{array}$ & Motivation \\
\hline Provision of social security scheme & $\mathbf{0 . 8 5 4}$ & 0.231 & -0.070 \\
\hline Role of trade unions & $\mathbf{0 . 8 3 8}$ & -0.203 & -0.163 \\
\hline Free market selection & $\mathbf{- 0 . 7 3 0}$ & 0.274 & $\mathbf{0 . 4 1 8}$ \\
\hline Training and Development & -0.026 & $\mathbf{0 . 9 3 5}$ & 0.133 \\
\hline Performance evaluation & -0.088 & $\mathbf{0 . 8 5 1}$ & $\mathbf{0 . 4 1 2}$ \\
\hline Performance-linked payment & -0.296 & 0.121 & $\mathbf{0 . 8 3 6}$ \\
\hline Employment involvement in & -0.102 & 0.366 & $\mathbf{0 . 7 9 8}$ \\
decision-making & & & \\
\hline
\end{tabular}


Table 6. $\quad$ Logistic Regression Results - Models 1-4

Relationships between HRM Practices and HRM Outcomes

\begin{tabular}{|c|c|c|c|c|c|c|c|c|}
\hline Variables entered & \multicolumn{2}{|c|}{$\begin{array}{l}\text { Model } 1 \\
\text { Staff turnover }\end{array}$} & \multicolumn{2}{|c|}{$\begin{array}{l}\text { Model } 2 \\
\text { Staff congruence }\end{array}$} & \multicolumn{2}{|c|}{$\begin{array}{l}\text { Model } 3 \\
\text { Staff competency }\end{array}$} & \multicolumn{2}{|c|}{$\begin{array}{l}\text { Model } 4 \\
\text { Staff commitment }\end{array}$} \\
\hline Constant $\beta_{0}$ & -2.596 & $(\mathrm{t}=-1.439)$ & -1.865 & $(\mathrm{t}=-.601)$ & -1.926 & $(\mathrm{t}=-.730)$ & -1.641 & $(\mathrm{t}=-.679)$ \\
\hline \multicolumn{9}{|l|}{ Three HRM practice factors } \\
\hline Social Benefits Factor & -.711 & $(\mathrm{t}=-1.238)$ & $-2.740 * * *$ & $(t=-2.857)$ & -.716 & $(t=-1.055)$ & $-1.435^{* *}$ & $(t=-1.876)$ \\
\hline Staff Development Factor & .005 & $(\mathrm{t}=.010)$ & 0.074 & $(\mathrm{t}=.165)$ & -325 & $(\mathrm{t}=-.697)$ & .794 & $(\mathrm{t}=1.505)$ \\
\hline Motivation Factor & $1.167 * * *$ & $(\mathrm{t}=2.772)$ & $1.896 * * *$ & $(t=3.076)$ & $1.205^{* *}$ & $(\mathrm{t}=2.536)$ & $1.637^{* * *}$ & $(\mathrm{t}=3.336)$ \\
\hline \multicolumn{9}{|l|}{ Control variables } \\
\hline Number of employees & $.001 *$ & $(\mathrm{t}=1.642)$ & .002 & $(\mathrm{t}=1.287)$ & .002 & $(\mathrm{t}=1.155)$ & .001 & $(\mathrm{t}=1.318)$ \\
\hline $\begin{array}{l}\text { Industry categories } \\
\text { - } \text { Business trading firms } \\
\text { - } \text { Manufacturing firms } \\
\text { - } \text { IT-related firms } \\
\text { - } \quad \text { Service firms } \\
\text { - } \text { Other non-categorized firms }\end{array}$ & $\begin{array}{l}-.173 \\
-1.234 \\
-1.222 \\
-1.510 \\
-\end{array}$ & $\begin{array}{l}(\mathrm{t}=-.125) \\
(\mathrm{t}=-.862) \\
(\mathrm{t}=-.961) \\
(\mathrm{t}=-1.046)\end{array}$ & $\begin{array}{l}-2.060 \\
-.787 \\
.830 \\
.293 \\
-\end{array}$ & $\begin{array}{l}(\mathrm{t}=-1.273) \\
(\mathrm{t}=-.546) \\
(\mathrm{t}=.581) \\
(\mathrm{t}=.180)\end{array}$ & $\begin{array}{l}-.498 \\
-3.686^{* *} \\
-1.452 \\
-1.290 \\
-\end{array}$ & $\begin{array}{l}(\mathrm{t}=-.317) \\
(\mathrm{t}=-2.177) \\
(\mathrm{t}=-1.115) \\
(\mathrm{t}=-.769)\end{array}$ & $\begin{array}{l}-.873 \\
-.995 \\
-.874 \\
-.733 \\
-\end{array}$ & $\begin{array}{l}(\mathrm{t}=-.524) \\
(\mathrm{t}=-.648) \\
(\mathrm{t}=-.645) \\
(\mathrm{t}=-.421)\end{array}$ \\
\hline $\begin{array}{l}\text { Enterprise ownership } \\
\text { - State-related enterprises } \\
\text { - Foreign-related enterprises } \\
\text { - Collective-related enterprises } \\
\text { - Domestic privately owned } \\
\text { enterprises }\end{array}$ & $\begin{array}{l}2.701^{* *} \\
3.416^{* *} \\
2.697^{*} \\
-\end{array}$ & $\begin{array}{l}(\mathrm{t}=2.161) \\
(\mathrm{t}=2.158) \\
(\mathrm{t}=1.773)\end{array}$ & $\begin{array}{l}2.303^{*} \\
5.144 * * * \\
3.319 * \\
-\end{array}$ & $\begin{array}{l}(\mathrm{t}=1.611) \\
(\mathrm{t}=2.641) \\
(\mathrm{t}=1.852)\end{array}$ & $\begin{array}{l}2.517^{*} \\
3.639^{* *} \\
3.520^{* *} \\
-\end{array}$ & $\begin{array}{l}(\mathrm{t}=1.676) \\
(\mathrm{t}=2.246) \\
(\mathrm{t}=2.212)\end{array}$ & $\begin{array}{l}2.866^{*} \\
1.954 \\
1.684 \\
-\end{array}$ & $\begin{array}{l}(\mathrm{t}=1.792) \\
(\mathrm{t}=1.151) \\
(\mathrm{t}=1.037)\end{array}$ \\
\hline Years of establishment & -.145 & $(\mathrm{t}=-1.036)$ & -.092 & $(\mathrm{t}=-.601)$ & -.114 & $(\mathrm{t}=-.712)$ & -.068 & $(\mathrm{t}=-.455)$ \\
\hline Technology application & 1.317 & $(\mathrm{t}=1.316)$ & .789 & $(\mathrm{t}=.639)$ & $3.620^{* * *}$ & $(\mathrm{t}=2.667)$ & 1.820 & $(\mathrm{t}=1.573)$ \\
\hline $\begin{array}{l}\text { Geographic location of firms } \\
\text { - Firms in Beijing and Tianjin } \\
\text { - Firms in Fuzhou and Xiamen } \\
\text { - Firms in Guangzhou and Shenzhen } \\
\text { - Firms in Hanzhou and Shanghai } \\
\text { - Firms in Kunming and Nanning }\end{array}$ & $\begin{array}{l}.626 \\
1.066 \\
1.597 \\
-.241 \\
-\end{array}$ & $\begin{array}{l}(\mathrm{t}=.379) \\
(\mathrm{t}=.765) \\
(\mathrm{t}=1.093) \\
(\mathrm{t}=-.163)\end{array}$ & $\begin{array}{l}1.918 \\
1.777 \\
1.838 \\
-1.104 \\
-\end{array}$ & $\begin{array}{l}(\mathrm{t}=1.022) \\
(\mathrm{t}=.983) \\
(\mathrm{t}=1.142) \\
(\mathrm{t}=-.644)\end{array}$ & $\begin{array}{l}1.461 \\
3.888^{*} \\
.921 \\
-.081 \\
-\end{array}$ & $\begin{array}{l}(\mathrm{t}=.851) \\
(\mathrm{t}=1.887) \\
(\mathrm{t}=.606) \\
(\mathrm{t}=-.050)\end{array}$ & $\begin{array}{l}.237 \\
1.345 \\
.113 \\
-.020 \\
-\end{array}$ & $\begin{array}{l}(\mathrm{t}=.127) \\
(\mathrm{t}=.763) \\
(\mathrm{t}=.069) \\
(\mathrm{t}=-.012)\end{array}$ \\
\hline Indicators for Model Fit & & & & & & & & \\
\hline $\begin{array}{l}\text { Chi-square }^{(1)} \\
\text { H-L test statistics } \\
\text { McFadden’s R }\end{array}$ & $\begin{array}{l}28.649 \\
.506 \\
.298\end{array}$ & & $\begin{array}{l}45.375^{* *}= \\
.617 \\
.451\end{array}$ & & $\begin{array}{l}30.342 * \\
.442 \\
.344\end{array}$ & & $\begin{array}{l}34.800^{* *} \\
.685 \\
.386\end{array}$ & \\
\hline
\end{tabular}

Notes: $\mathrm{p}<0.1^{*}, \mathrm{p}<0.05^{* *}, \mathrm{p}<0.01^{* * *}$

(1) Model chi-square used to test the overall significance of a model.

(2) The Hosmer and Lemeshow (H-L) test statistics is an indicator of goodness-of-fit in the model, when the values is greater than 0.05 , the model is desirable.

(3) The values of McFadden's $\mathrm{R}^{2}$ between 0.2 to 0.4 in a logistic regression are considered to be extremely good fits (Hensher \& Johnson 1981 , p. 51). 
Zheng et al. 2006/7 - International Journal of Human Resource Management - in press

Table 7. Rotated Component Matrix for HRM Outcome and Firm Performance Variables

\begin{tabular}{|l|c|c|}
\hline \multicolumn{3}{|c|}{ Rotated Component Matrix } \\
\hline HRM Outcome Variables & $\mathbf{1}$ & $\mathbf{2}$ \\
\hline Staff commitment & $\mathbf{0 . 8 8 9}$ & 0.213 \\
\hline Staff congruence & $\mathbf{0 . 8 7 4}$ & 0.193 \\
\hline Staff turnover & $\mathbf{0 . 7 5 9}$ & $\mathbf{0 . 4 3 9}$ \\
\hline Staff competence & 0.249 & $\mathbf{0 . 9 5 8}$ \\
\hline
\end{tabular}


Table 8. $\quad$ Logistic Regression Results - Models 5-7

Relationship between HRM Outcomes and Enterprise Performance

\begin{tabular}{|c|c|c|c|c|c|c|}
\hline Variables entered & \multicolumn{2}{|c|}{$\begin{array}{l}\text { Model } 5 \\
\text { Increasing Sales/Production }\end{array}$} & \multicolumn{2}{|c|}{$\begin{array}{l}\text { Model } 6 \\
\text { Market Competitiveness }\end{array}$} & \multicolumn{2}{|c|}{$\begin{array}{l}\text { Model } 7 \\
\text { Expected Growth }\end{array}$} \\
\hline Constant $\beta_{0}$ & $3.633^{* *}$ & $(\mathrm{t}=2.025)$ & 2.317 & $(\mathrm{t}=1.502)$ & $2.198 *$ & $(\mathrm{t}=1.749)$ \\
\hline Three HRM outcome factors & & & & & & \\
\hline $\begin{array}{l}\text { Staff Commitment Factor } \\
\text { Staff Competency Factor }\end{array}$ & $\begin{array}{l}1.898^{* * *} \\
.719 *\end{array}$ & $\begin{array}{l}(\mathrm{t}=3.761) \\
(\mathrm{t}=1.661)\end{array}$ & $\begin{array}{l}.852^{* * *} \\
.541\end{array}$ & $\begin{array}{l}(\mathrm{t}=2.574) \\
(\mathrm{t}=1.599)\end{array}$ & $\begin{array}{l}.952 * * * \\
.558^{*}\end{array}$ & $\begin{array}{l}(\mathrm{t}=3.125) \\
(\mathrm{t}=1.823)\end{array}$ \\
\hline Control variables & & & & & & \\
\hline Number of employees & .006 & $(\mathrm{t}=1.338)$ & .004 & $(\mathrm{t}=1.183)$ & .000 & $(\mathrm{t}=.446)$ \\
\hline \begin{tabular}{ll}
\multicolumn{2}{l}{ Industry categories } \\
$-\quad$ Business trading firms \\
$-\quad$ Manufacturing firms \\
$-\quad$ IT-related firms \\
$-\quad$ Service firms \\
$-\quad$ Other non-categorized firms
\end{tabular} & $\begin{array}{l}-2.531^{*} \\
.825 \\
1.196 \\
-.769 \\
-\end{array}$ & $\begin{array}{l}(\mathrm{t}=-1.664) \\
(\mathrm{t}=-.599) \\
(\mathrm{t}=.719) \\
(\mathrm{t}=-.512)\end{array}$ & $\begin{array}{l}-2.779 * \\
-1.093 \\
-2.356^{*} \\
-2.016 \\
-\end{array}$ & $\begin{array}{l}(\mathrm{t}=-1.883) \\
(\mathrm{t}=-.807) \\
(\mathrm{t}=-1.732) \\
(\mathrm{t}=-1.369)\end{array}$ & $\begin{array}{l}-.365 \\
-.201 \\
-1.459 \\
-.548 \\
-\end{array}$ & $\begin{array}{l}(\mathrm{t}=-.299) \\
(\mathrm{t}=-.175) \\
(\mathrm{t}=-1.286) \\
(\mathrm{t}=-.419)\end{array}$ \\
\hline $\begin{array}{ll}\text { Enterprise ownership } \\
\text { - } & \text { State-related enterprises } \\
- & \text { Foreign-related enterprises } \\
- & \text { Collective-related enterprises } \\
\text { - } & \text { Domestic private owned enterprises }\end{array}$ & $\begin{array}{l}-.476 \\
-1.852 \\
-1.833 \\
-\end{array}$ & $\begin{array}{l}(\mathrm{t}=-.428) \\
(\mathrm{t}=-1.204) \\
(\mathrm{t}=-1.302)\end{array}$ & $\begin{array}{l}-.360 \\
-.281 \\
-.482 \\
-\end{array}$ & $\begin{array}{l}(\mathrm{t}=-.424) \\
(\mathrm{t}=-.257) \\
(\mathrm{t}=-.484)\end{array}$ & $\begin{array}{l}-.382 \\
.201 \\
.541 \\
-\end{array}$ & $\begin{array}{l}(\mathrm{t}=-.462) \\
(\mathrm{t}=.184) \\
(\mathrm{t}=.493)\end{array}$ \\
\hline Years of establishment & .006 & $(\mathrm{t}=.032)$ & .168 & $(\mathrm{t}=1.205)$ & -.097 & $(\mathrm{t}=-.744)$ \\
\hline Technology application & $-2.691^{* *}$ & $(\mathrm{t}=-2.110)$ & -.824 & $(\mathrm{t}=-.894)$ & .184 & $(\mathrm{t}=.192)$ \\
\hline Indicators for Model Fit & & & & & & \\
\hline $\begin{array}{l}\text { Chi-square } \\
\text { H-L test statistics } \\
\text { McFadden's } \mathrm{R}^{2}\end{array}$ & $\begin{array}{l}42.968^{* * *} \\
.311 \\
.477\end{array}$ & & $\begin{array}{l}22.139 * * \\
.612 \\
.250\end{array}$ & & $\begin{array}{l}20.546^{*} \\
.658 \\
.238\end{array}$ & \\
\hline
\end{tabular}

